University of Nebraska - Lincoln

DigitalCommons@University of Nebraska - Lincoln

Papers in the Earth and Atmospheric Sciences

Earth and Atmospheric Sciences, Department

$10-2009$

\title{
Evolution of the Cretaceous calcareous nannofossil genus Eiffellithus and its biostratigraphic significance
}

\author{
J. L. Shamrock \\ University of Nebraska-Lincoln, jshamroc@bigred.unl.edu \\ David K. Watkins \\ University of Nebraska-Lincoln, dwatkins1@unl.edu
}

Follow this and additional works at: https://digitalcommons.unl.edu/geosciencefacpub

Part of the Earth Sciences Commons

Shamrock, J. L. and Watkins, David K., "Evolution of the Cretaceous calcareous nannofossil genus Eiffellithus and its biostratigraphic significance" (2009). Papers in the Earth and Atmospheric Sciences. 201.

https://digitalcommons.unl.edu/geosciencefacpub/201

This Article is brought to you for free and open access by the Earth and Atmospheric Sciences, Department of at DigitalCommons@University of Nebraska - Lincoln. It has been accepted for inclusion in Papers in the Earth and Atmospheric Sciences by an authorized administrator of DigitalCommons@University of Nebraska - Lincoln. 


\title{
Evolution of the Cretaceous calcareous nannofossil genus Eiffellithus and its biostratigraphic significance
}

\author{
J. L. Shamrock and D. K. Watkins \\ Department of Geosciences, University of Nebraska-Lincoln, Lincoln, Nebraska 68588-0340, USA \\ Corresponding author - J. L. Shamrock, e-mail jshamroc@bigred.unl.edu
}

\begin{abstract}
The calcareous nannofossil genus Eiffellithus is an important taxon of mid- to Upper Cretaceous marine sediments in biostratigraphy and paleoceanography. The definition of species within Eiffellithus have been both broadly interpreted and variably applied by nannofossil workers. This is particularly true for the Eiffellithus eximius plexus. While the taxonomy of mid-Cretaceous Eiffellithus species has recently been well-defined, the remaining 35 m.y. history of the genus has not been closely examined. Our investigation of Cenomanian to Maastrichtian sediments from the Western Interior Seaway, Gulf of Mexico, and Western Atlantic gives rise to six new species of Eiffellithus that can be reliably differentiated. In this paper the hitherto used biostratigraphic markers (E. turriseiffelii and E. eximius) have been redefined in a more restricted sense to increase their utility. These refinements in taxonomy reveal an obvious shift in abundance both within the genus and within the nannofossil assemblage as a whole through the Late Cretaceous. In the Cenomanian and Maastrichtian the genus is composed exclusively of coccoliths bearing an X-shaped central cross, such as E. turriseiffelii, while in the Coniacian through Campanian axial-cross forms such as E. eximius comprise more than $60 \%$ of the genus. Within the nannofossil assemblage the genus has low abundances in the Cenomanian but increases to $>15 \%$ of the assemblage in well-preserved samples in the Santonian. In addition, the pattern of diversification of this genus, whereby a $x$-shaped, diagonal cross repeatedly gives rise to an axial cross by rotation about the central axis, is an excellent example of iterative evolution that may be related to repetitive shifts in Late Cretaceous climatic and paleoceanographic regimes.
\end{abstract}

Keywords: Upper Cretaceous, nannofossils, biostratigraphy, taxonomy, Eiffellithus

\section{Introduction}

Since the original description of the genus Eiffellithus by Deflandre and Fert (1954), various nannofossil workers have noted the obvious, often striking, interspecies variation within its most prominent species (Verbeek, 1977; PerchNielsen, 1968, 1973, 1979, 1985; Watkins and Bergen, 2003). This morphological variability is linked both to the construction of the coccolith itself and to a poorly defined taxonomy. These inconsistencies have generated a wealth of literature that debates and refines the morphological characteristics that distinguish two historical end-members: Eiffellithus turriseiffelii (Deflandre and Fert, 1954; Reinhardt, 1965) and E. eximius (Stover, 1966; Perch-Nielsen, 1968). There has been little consensus within the nannofossil community with respect to discrete morphotypes, species descriptions, and evolutionary lineages (Gartner, 1968; Hill, 1976; Verbeek, 1977; PerchNielsen, 1968, 1973, 1979, 1985; Hill and Bralower, 1987; Watkins and Bergen, 2003).
The type-species for this genus, E. turriseiffelii, was one of the first calcareous nannofossil markers used in biostratigraphy. Both E. turriseiffelii and E. eximius are currently used as biostratigraphic datums in the Roth (1978) NC Zonation, Perch-Nielsen (1985) CC Zonation, and the Burnett and Whitham (1999) UC Zonation for calcareous nannofossils. Species within the genus display key characteristics of strong index fossils: Eiffellithus is dissolution resistant (Thierstein, 1980) and shows a rapid rate of evolution after its first appearance datum (FAD) in the upper Albian. The genus Eiffellithus is an abundant and ubiquitous component of Late Cretaceous nannofossil assemblages, reaching maximum abundances of up to $15-20 \%$ in well-preserved Santonian samples.

Previous work on the early diversification by Perch-Nielsen (1985) and Watkins and Bergen (2003) provide a well-defined taxonomy for the genus for the late Albian - middle Cenomanian. Despite the high abundance of this genus throughout the Late Cretaceous, these later forms remain largely undefined. The current study develops a more refined taxonomy for this 
period and defines the morphological diversity and variability present in these Eiffellithus assemblages. This taxonomic framework aids in biostratigraphy, particularly when one considers the likelihood of polytaxic markers in current Eiffellithus datums.

In this study, over 9000 specimens of Eiffellithus from the Upper Cretaceous were examined to verify the ranges of current biostratigraphic markers, to define the taxonomic relationships between discrete morphotypes, and to examine the potential source of variability expressed by these forms. This study identifies numerous new species and potential biostratigraphic datums and gives an excellent demonstration of iterative evolution.

\section{Site localities}

Samples were selected from five localities: three in the Western Interior Basin (Washington Co., KS; Smoky Hill type area; Sisseton, SD) and two North American deep water localities (DSDP Leg 10-95; ODP Leg 171b-1049A/1050C) (Figure 1). Sites were selected based on good average preservation of calcareous nannofossils and best stratigraphic coverage (Figure 2). Due to the variation in both depositional and recovery thickness, samples were taken at regular intervals at each locality in order to maximize sampling from the available materials while generating a regular sample spacing throughout the column with respect to time. A total of 201 samples were used in final analysis. Samples with very low nannofossil abundance $(\leq 5 \%$ sediment volume) were excluded, as well as samples with poor preservation, where over-growth or dissolution obscures key morphological characteristics.

Greenhorn Limestone samples were collected from outcrop in North-central Kansas (Washington Co.) at Localities 6-7 of Hattin (1975), whose work provides a detailed lithologic description of each locality. Samples were collected at 10-20 cm intervals through $16.35 \mathrm{~m}$ of section, and consisted primarily of chalky limestone from the top of the Lincoln Member (Mbr) through the Pfeiffer Member. This site contains the oldest sediments examined in this study, from the base of the middle Cenomanian through the lower Turonian, with good coverage of the Cenomanian-Turonian boundary. Due to varying preservation, 69 of 115 samples were used in final analysis. First appearance datums from this section have been dated by correlation of marker units of Sageman et al. (1998). Dates are tentative and are given to estimate the timing of evolutionary events.

The Niobrara Chalk Formation (Fm) was sampled from outcrop at the Smokey Hill type area of Hattin (1982) in west central Kansas. The type area consists of a series of localities that spans the entire lithologic section, with Hattin's study (1982) providing very detailed stratigraphic and lithologic descriptions of each type locality. The section was sampled over $191 \mathrm{~m}$ at $1 \mathrm{~m}$ intervals, and consists of nannofossil rich chalks, for which the formation is named. This sample set includes the Fort Hayes and Smoky Hill Mbrs, with good coverage from the Coniacian -lower Campanian. From the 191 original samples, 103 were closely examined for their excellent preservation and stratigraphic distribution.

Deep Sea Drilling Program (DSDP) Leg 10, Site 95 is located on the Campeche Scarp face of the Yucatan Shelf in the Gulf of Mexico. Sediments consist of nannofossil chalk and foraminifera-nannofossil chalk to ooze, with thin intervals of chert clasts. Reports from DSDP Leg 10 by Worzel et al. (1973) give lithologic descriptions and stratigraphic distributions for this

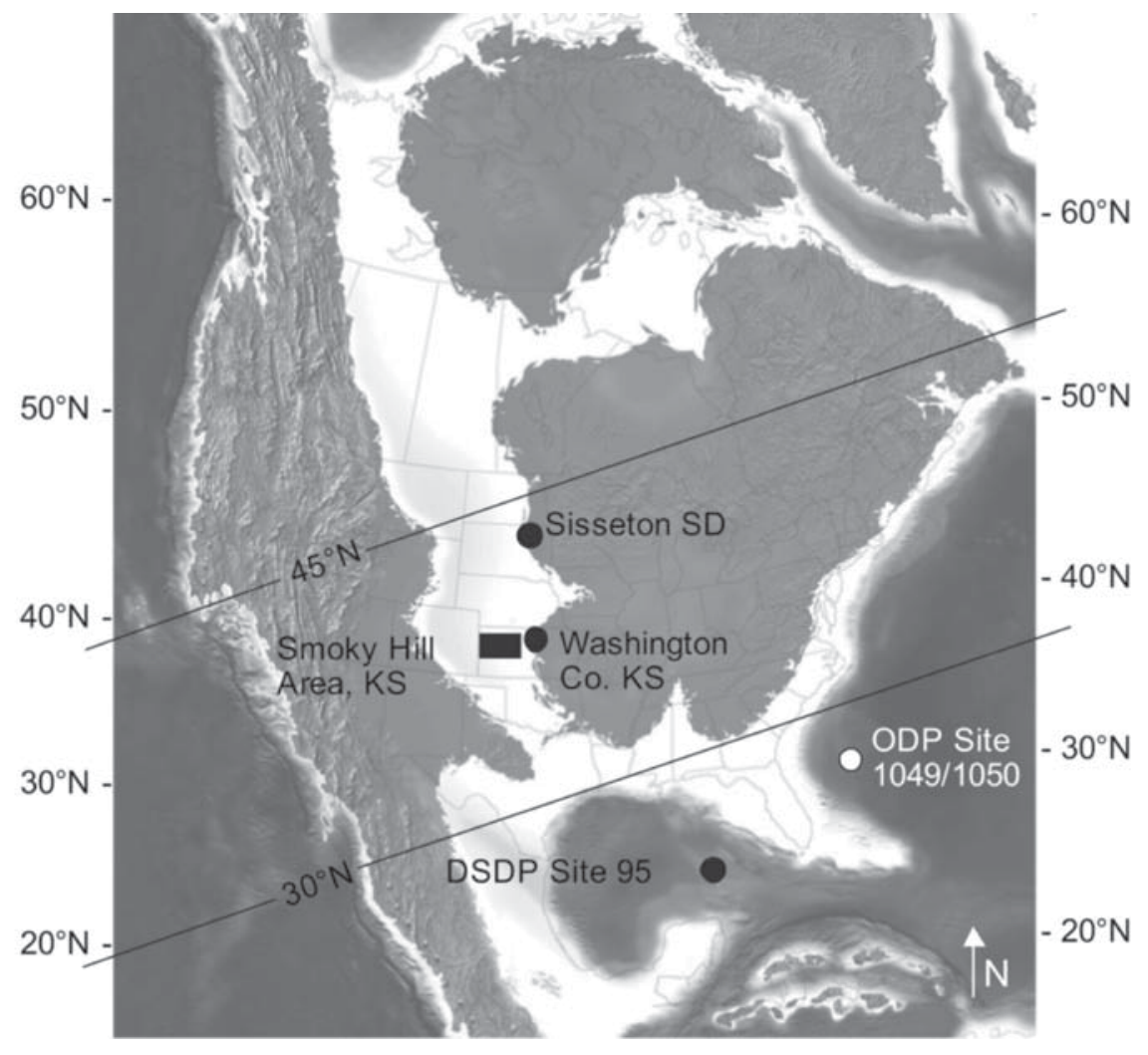

Figure 1. Geographical distribution of the five localities examined in this study, three in the Western Interior Basin (Washington Co., KS; Smoky Hill type area; Sisseton, SD) and two North American deep water localities (DSDP Leg 10-95; ODP Leg 171b-1049A/1050C). Sites were correlated to create a composite Late Cretaceous section. Paleolatitudes lines at $30^{\circ}$ and $45^{\circ}$ are also shown. 

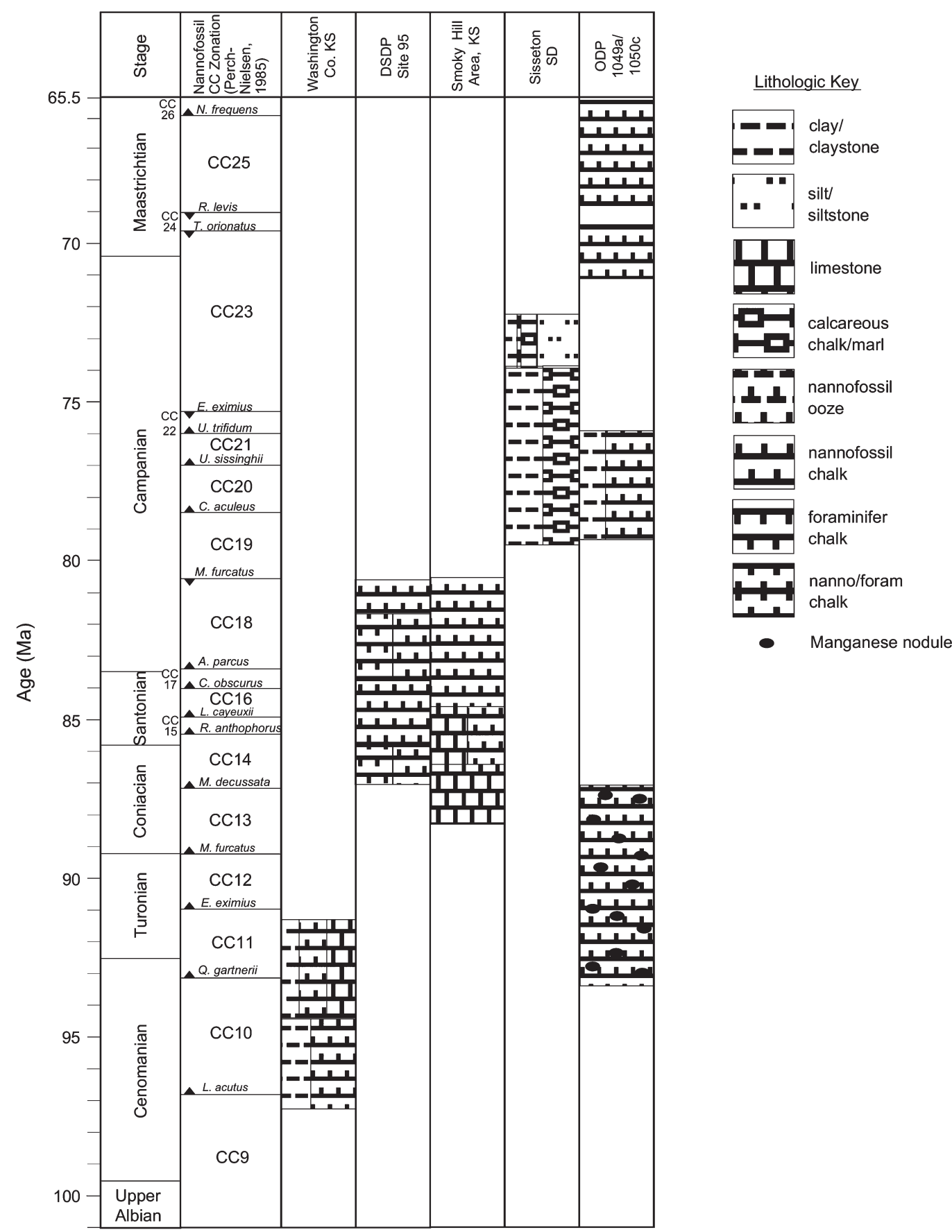

Figure 2. Stratigraphic distribution of calcareous sediments examined through the five sites in this study, correlated to geologic stage and PerchNielsen's, 1985 CC Zonation for calcareous nannofossils.

site. Cores were sampled through the entire $42 \mathrm{~m}$ of Late Cretaceous sediments. Cores 13-18 were sampled with as regular a spacing as possible; however, some cores have poor recovery and/or loss of structure. A total of 48 samples were included in this study, spanning the upper Santonian-lower Campanian, with good average preservation.

The Pierre Shale Group was sampled from a subsurface core in Sisseton, South Dakota. Sediments consist of nannofossil chalk and calcareous marl/claystone with intervals of siliciclastics and bentonites. The lithology and stratigraphy is detailed by Schultz et al. (1980) and Hanczaryk and Gallagher (2007). The interval studied (Cores 11-32; 33.5-97.5 meters below surface) includes the Crow Creek Mbr. of the De Gray Fm. and the Gregory Fm. of the Pierre Shale, and provides an ex- panded section of the middle-upper Campanian. The quality of sediments above and below this interval prohibits use in this study. Though this site provides some well-preserved materials, a total of 38 samples were used in final analysis, as portions of the core have very poor preservation and/or low nannofossil abundance.

Two sites from Ocean Drilling Program (ODP) Leg 171B, along the eastern margin of Blake Nose, were examined specifically for preservation of Turonian, upper Campanian, and Maastrichtian nannofossils. Sediments consist of clayey nannofossil ooze and chalk. The Shipboard Scientific Party, et al. (1998) provide a detailed stratigraphic and lithologic description of these sites. A total of 33 samples were selected from Hole 1049A, cores 17-19, and Hole 1050C, cores 


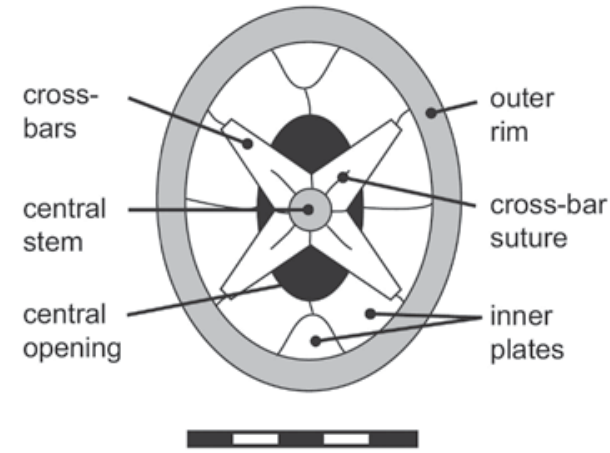

Figure 3. General structure of Eiffellithus specimens. Scale bar $=5 \mu \mathrm{m}$.

11-20, with well preserved nannofossils throughout these selected intervals.

\section{Methods}

Samples from DSDP Leg 10, Site 95 were prepared using a combined random settling and microsphere spiking procedure as detailed in Geisen et al. (1999), which provides consistent, reproducible results in calculating the absolute abundances of calcareous nannoplankton. Variation in settling device set-up as outlined in Geisen et al. (1999) is limited to a cylinder diameter increase from $80 \mathrm{~mm}$ to $120 \mathrm{~mm}$, which does not affect abundance calculations. Slides from samples in the Western Interior Seaway and ODP Sites 1049A and 1050C were prepared using the double slurry method (Watkins and Bergen, 2003). Slides were viewed on a Zeiss Photoscope III at 1250x magnification using phase contrast, plane-polarized light, cross-polarized light, and a one-quarter $\lambda$ mica plate.

Specimens were digitally photographed and analyzed using ImageJ 1.37, a JAVA-based digital image processing program with a resolution of $\sim 0.20 \mu \mathrm{m}$ (Rasband, 1997-2006). Morphological data (Figure 4) were analyzed using PAST (Hammer et al., 2001).

\section{Physical characteristics and current taxonomy}

The genus Eiffellithus is characterized by elliptical coccoliths with a distinct outer rim, infilled by overlapping back plates, bearing four disjunct cross-bars that support a large stem. The outer rim shows a smooth to serrate outline of $\sim 30$ 80 blocky, imbricated elements, and the inner cycle is formed by $8-15$ thin, triangular to polygonal plates. These inner plates can fill the central area or join to create an elliptical opening, $p$
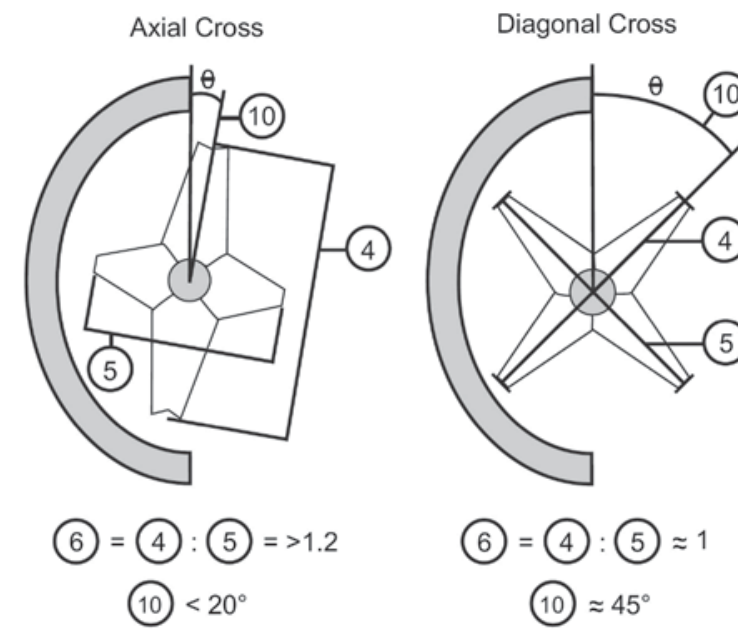

Figure 4. Stylized diagram illustrating the morphological variables measured in this study: 1) coccolith length, 2) coccolith width, 3) eccentricity, 4) longitudinal cross-bar length, 5) transverse cross-bar length, 6) cross-bar ratio, 7) number of longitudinal cross terminations, 8) number of transverse cross terminations, 9) total number of cross terminations, and 10) the angle of the larger cross-bar to the longitudinal axis of the ellipse. Cross-bar terminal morphology and numeric correlations are also shown.

articularly in earlier forms. This opening may be obscured by the stem-supporting central cross, which sits above the plane of the rims. The four cross-bars are composed of thin, lath-like crystallites. The presence or absence of the stem can greatly affect a specimen's appearance, indicated by Reinhardt's (1965) description of Eiffellithus turriseiffelii inturratus ssp., a stemless version of E. turriseiffelii. When present, the central stem appears solid or as a small circular opening. In well-preserved specimens the stem can appear as a ring of crystallites in the cross center. When absent, a prominent, square or diamond-shaped opening in the cross base spans $20-35 \%$ of the transverse axis in large specimens. Smaller morphotypes retain their stems more frequently than larger specimens such as E. turriseiffelii, this relationship likely related to the relative increase in stem height with specimen size and a greater tendency of breakage in taller structures.

The variability of distinct morphological characteristics has not been utilized to distinguish unique morphotypes within the genus. The current mode of classification for Eiffellithus is based on the original description of Clinorhabdus eximius Stover 1966, distinguished from the type-species Eiffellithus turriseiffelii by a "differentially oriented axial structure with respect to the axes

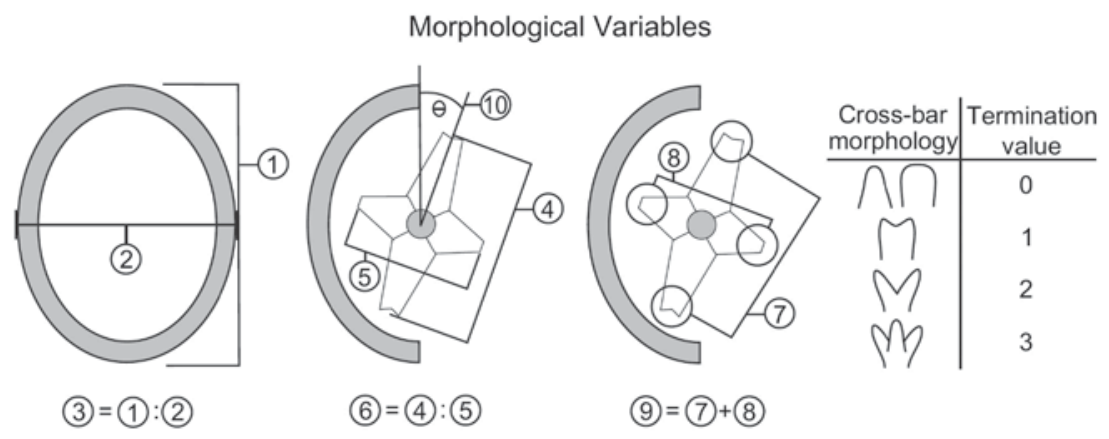

Figure 5. Stylized diagram illustrating the relationship between variable 6 (cross-bar ratio) and variable 10 (angle between cross-bar and longitudinal axis of the ellipse), for an axial cross (A) versus a diagonal cross (B). As the value of variable 10 decreases the value of variable 6 increases, so the ratio of cross-bar lengths is least when the cross-bars are furthest from the long axis (a diagonal cross), and greatest when the cross bars are nearest to the long axis (axial cross). 
of the coccolith," (Stover, 1966, p.138). This classification splits many distinct morphotypes into two categories: an axial cross or a diagonal cross. A pervasive binary approach is shown in Hill (1976) where "forms which are intermediate between these species [E. turriseiffelii and E. eximius] rarely exist," (p. 139) and "specimens of Gartner (1968) and Manivit (1971) that are regarded as non-E. turriseffelii are considered to be E. eximius," (p. 140). For such reasons, inconsistencies persist in the genus taxonomy and the biostratigraphic markers E. eximius and E. turriseffelii remain polytaxic.

Authors such as Verbeek (1977) have refined the turriseffelii) eximius classification by placing limits on the angle made by the longitudinal cross-bar with the major axis of the ellipse. PerchNielsen $(1979,1985)$ examined the type material of both E. turriseiffelii and E. eximius to clarify the original descriptions and to develop a tentative lineage for the genus, with numerous morphotypes informally described using a large body of qualitative criteria (1985, Figure 12). Two of these morphotypes were given formal systematic descriptions as Albian species by Watkins and Bergen (2003). To date, there has been little discussion beyond Perch-Nielsen (1985) of distinct Late Cretaceous morphologies, either within these two polytaxic end-members or with respect to intermediate forms.

\section{Data collection and preliminary results}

After examining the general structure of Eiffellithus specimens (Figure 3), we developed a set of morphological criteria that best characterizes the variability expressed within the genus. Ten quantitative characteristics (Figure 4) were measured and analyzed: 1) coccolith length, 2) coccolith width, 3) eccentricity, 4) longitudinal cross-bar length, 5) transverse cross-bar length, 6) cross-bar ratio, 7) number of longitudinal cross terminations, 8) number of transverse cross terminations, 9) total number of cross terminations, and 10) the angle of the midline of the larger crossbar to the longitudinal axis of the ellipse. Further reference to these characteristics, or variables, will be made with respect to these assigned numbers, such as V-1 for coccolith length.

For symmetrical diagonal forms, where all cross-bars are approximately equidistant from the long axis $\left(\sim 45^{\circ}\right)$, angular data represent the average of two cross-bars (one above and one below the transverse axis). For terminal morphology, a value of zero was assigned to cross-bars with a distinctly pointed to blunt termination. A value of one represents cross-bars with a weakly forked tip. A value of two indicates a widely bifurcate morphology, while distinctly trifurcate crossbars were assigned a value of three. Additional qualitative characteristics such as birefringence patterns and intensity, structural relief, plate thickness, and preservational effects were also considered in this study. Specimen descriptions follow the "Guidelines for coccolith and calcareous nannofossil terminology" (Young et al., 1997).

All 9,000 specimens were used in preliminary analysis. Principal component analysis (PCA) was performed on a correlation matrix, to analyze the relationships among these morphological variables. A correlation matrix was used as morphological data were measured in different units. The first principal component accounted for $54.8 \%$ of the variance. Four loadings have similar correlations $(\sim 0.5)$ to this component, but all pertain to aspects of size of the coccolith and central cross (V-1, 2, 4, and 5). The second principal component accounts for $18.5 \%$ of the total variance. The shape of the cross, represented by the ratio of cross-bar lengths (V-6), has the greatest correlation to this component (0.925). The angle

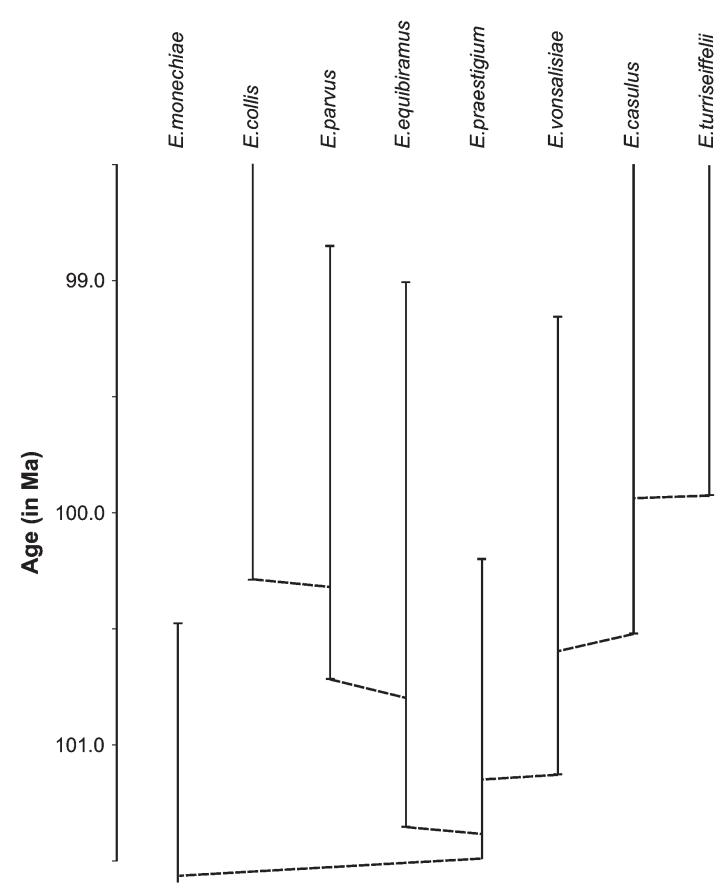

Figure 6. Late Albian to early Cenomanian lineage of the genus Eiffellithus, modified from Watkins and Bergen (2003).

of the cross to the longitudinal axis of the ellipse (V-10) had the strongest inverse correlation to this component $(-0.558)$. Structurally this correlation is sound: as the value of variable 10 decreases the value of variable 6 increases (Figure 5), so the ratio of cross-bar lengths is least when the cross-bars are furthest from the long axis (a diagonal cross), and greatest when the cross-bars are nearest to the long axis (axial cross). For the third principal component, the angle of the cross-bars has the highest positive loading (0.5897), while the total amount of cross-bar bifurcation (V-9) had the highest negative loading $(-0.7162)$. This component accounts for $11.5 \%$ of the total variance. In summation, these three components represent $84.8 \%$ of the total variance within the Eiffellithus assemblage.

Some basic morphological principals were confirmed from this analysis: when comparing specimens through a morphological transition from a diagonal cross to an axial cross, the

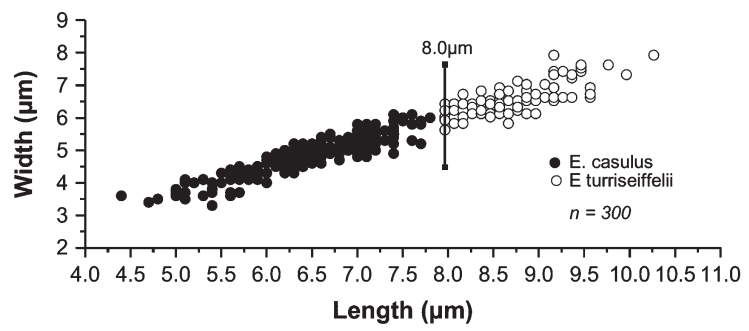

Figure 7. Length vs. width relationship showing size variation in specimens previously classified as Eiffellithus turriseiffelii $(\mathrm{n}=300)$. A clear distribution break can be seen near $8.0 \mu \mathrm{m}$. Approximately $95 \%$ of specimens are $>8.0 \mu \mathrm{m}$ or $<7.5 \mu \mathrm{m}$ in length, with $<5 \%$ of specimens falling between these ranges. While specimens of all lengths are present, this size range is much less abundant than the specimens on either size of this range. E. casulus n. sp. includes specimens $<8.0 \mu \mathrm{m}$ in length, and is the first to appear at $100.5 \mathrm{Ma}$ (Watkins and Bergen), while of E. turriseiffelii (> $8.0 \mu \mathrm{m}$ in length) appears at $99.9 \mathrm{Ma}$, approximately $0.6 \mathrm{~m} . \mathrm{y}$. afterward $\left(\mathrm{p}_{\text {same length }}=2.72 \mathrm{E}^{-27} ; \mathrm{p}_{\text {same }}\right.$ width $=2.48 \mathrm{E}^{-32}$ ). The division appears to bisect specimens, but is only a result of the large circular markers centered over data points. 


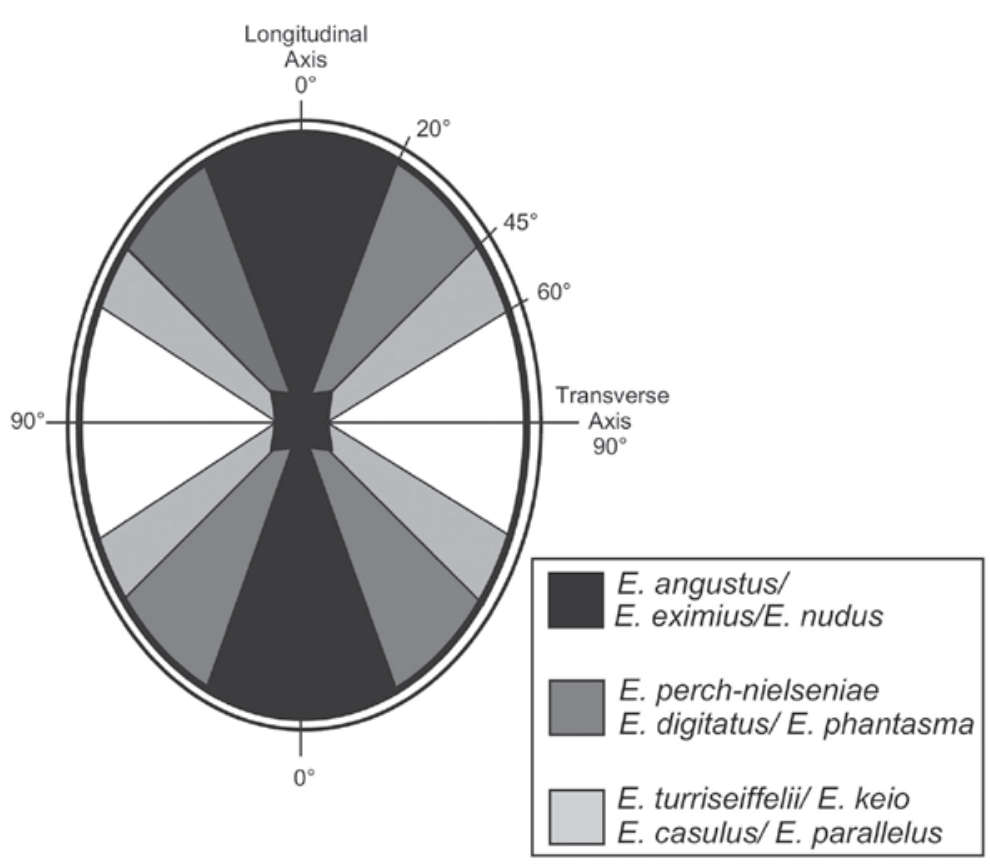

Figure 8. Diagram illustrating the relationship among species of Eiffellithus with respect to the mid-line of the longitudinal cross-bars. As E. turriseiffelii-like forms are symmetrical about the axis, neither pair of crossbars can be differentiated as the longitudinal arms. A central cross is intermediately oriented when the mid-line of the longitudinal cross-bar falls between $20^{\circ}-44^{\circ}$ of the longitudinal axis of the ellipse. Axial forms are recognized when the mid-line of the larger crossbars falls within $20^{\circ}$ of the longitudinal axis of the ellipse, forming a symmetrical to slightly asymmetrical axial cross.

most significant characteristic in distinguishing morphotypes is the angle between the cross-bar and the longitudinal axis. The ratio of cross-bar lengths is the second most diagnostic feature in these morphological sequences. The size of the coccolith and number of cross-bar terminations (V-7, 8, and 9) are the most significant criteria for differentiating morphotypes when comparing specimens with similarly oriented central crosses. By these principals, approximately 10 potential morphotypes were developed. These morphotypes differed with respect to size, cross orientation and construction, and crossbar distal morphology.

A representative sample of 50 specimens/morphotype was randomly selected from the larger database for further analysis, unless specifically noted. Only 30 specimens were used in the data analysis of E. keio n. sp. as it has low preservation potential, being somewhat rare, thinly constructed, and of short range.

Counts of 300 specimens/slide were performed on a total of 66 slides, to determine the total relative abundance of Eiffellithus in the nannofossil assemblage, and to analyze the general morphological trends within the genus with respect to the angular orientation of the central cross. Eiffellithus species were grouped as in Figure 7. As shown by Thierstein (1980), Eiffellithus is dissolution-resistant and, therefore, susceptible to abnormally high abundance values in poorly preserved samples. To avoid such bias, care was taken to select specimens with good overall preservation and high species richness. When possible, multiple samples were examined from the same stratigraphic horizon to compare the relative abundance at different sites.

These data are archived at Shamrock and Watkins (2008). The results of these analyses are incorporated into the text, figures, and systematic paleontology below.

\section{Lower Cretaceous taxonomy}

The genus Eiffellithus first appeared in the upper Albian from Vekshinella angusta (Stover 1966) Verbeek 1977, and rapidly diversified in the early part of its range below the Albian-Cenomanian boundary. Eiffellithus monechiae (Crux 1991) Watkins and Bergen 2003, the first species of the genus, gave rise to seven new taxa between $\sim 101.5-99.5 \mathrm{Ma}$. This Lower Cretaceous lineage is shown in Figure 6, modified from Watkins and Bergen (2003).

Eiffellithus turriseiffelii shows at least two distinct morphotypes by the uppermost Albian. The original description of E. turriseiffelii does not state the size, though the holotype has been measured from micrographs to be $\sim 9.2 \mu \mathrm{m}$ along the long axis (V-1). No paratype was provided to account for the distinctly smaller morphotype (length $=5-8 \mu \mathrm{m}$ ). Watkins and Bergen (2003) showed that the large morphotype of E. turriseiffelii $(>8.0 \mu \mathrm{m})$ does not appear until $99.9 \mathrm{Ma}$, approximately 0.6 m.y. after the FAD of E. turriseffelii (small) at 100.5 Ma. Perch-Nielsen (1968) noted that the small and large morphotypes represent distinct populations, with specimens of intermediate size less frequently observed.

Analysis of the length and width of 300 specimens of $E$. turriseffelii from the Cenomanian-Maastrichtian in the present study has confirmed the presence of two morphotypes (Figure 7), with a clear distribution break at $8.0 \mu \mathrm{m}$. F- and T-tests show two distinct populations ( $\mathrm{p}_{\text {same length }}=2.72 \mathrm{E}^{-27}$; $\mathrm{p}_{\text {same width }}=2.48 \mathrm{E}^{-32}$ ). The small morphotype of E. turriseiffelii, herein $E$. casulus n.sp., has an average length of $6.0 \mu \mathrm{m}$ (max $<8 \mu \mathrm{m})$. The larger E. turriseiffelii has an average length of $8.7 \mu \mathrm{m}$ (holotype $9.2 \mu \mathrm{m}, \mathrm{min}>8 \mu \mathrm{m}$ ). A typical field of view of Upper Cretaceous sediment contains specimens of E. turriseiffelii that are often 2-3 times larger than E. casulus. Subsequent diversifications from this lineage gave rise to species of Eiffellithus observed in Upper Cretaceous assemblages.

\section{Upper Cretaceous taxonomy}

At the start of the Late Cretaceous all forms of Eiffellithus bear a symmetrical diagonal cross, with the midline of the crossbars $45^{\circ}-60^{\circ}$ from the longitudinal axis (Figures 8 \& 9). Eiffellithus turriseiffelii, E. casulus, and E. collis represent the entire genus through much of the Cenomanian. A new period of diversification began in the upper Cenomanian, giving rise to more ornate morphotypes and intermediately oriented forms (Figure 9).

Perch-Nielsen (1985, Figure 12) illustrates two morphotypes of E. turriseiffelii: Eiffellithus turriseiffelii $A$ has thinner 


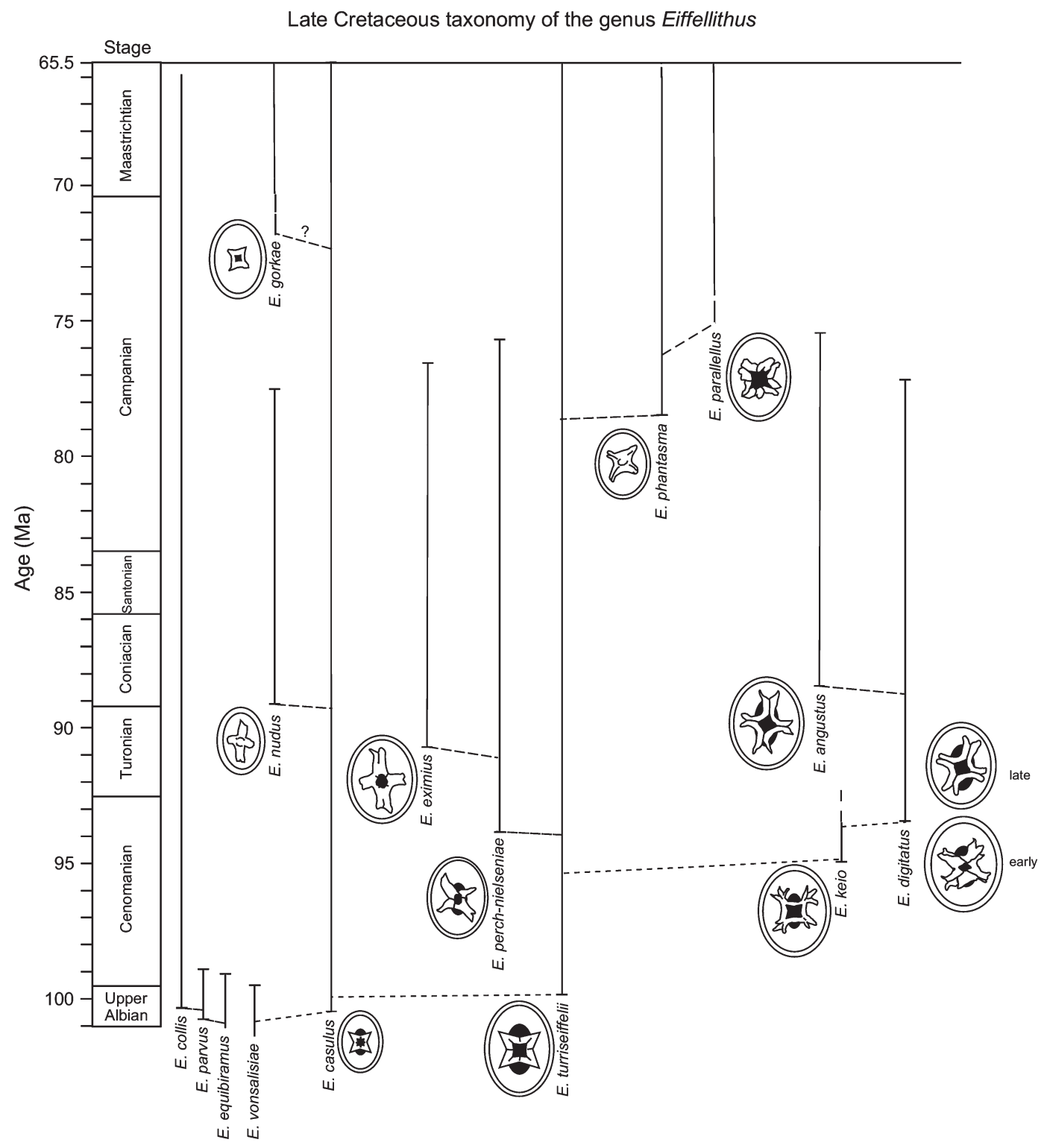

Figure 9. Working lineage for species of Eiffellithus through the Upper Cretaceous.

plates, cross-bars at $\sim 90^{\circ}$, and a large central opening. Eiffellithus turriseiffelii s.str. has thicker plates, cross-bars forming two obtuse and two acute angles, and distinctly pointed cross-bar terminations. These observations have been verified in this study, with the robust, pointed E. turriseiffelii s.str. far more abundant and morphologically consistent. This morphotype corresponds to the original sketch of Deflandre and Fert (1954, Figure 65), which clearly shows a cross centered about both coccolith axes, with symmetrical, tapered cross-bars. Nearly all interspecies variation is due to differences in size or presence of slightly forked cross-bar terminations from the lathlike construction of the central cross.

Eiffellithus turriseiffelii A, herein E. keio n.sp., is much less abundant and most frequently preserved as broken specimens due to a thinner plate construction. The central cross of E. keio can appear slightly asymmetrical due to variability in bifurcate to trifurcate cross-bar terminations, but is centered about the coccolith axes. While Perch-Nielsen did not formally separate these two morphotypes, the structural transitions that begin in E. keio lead to a variety of morphologically distinct forms previously included in the E. eximius species complex (Figure 9). Eiffellithus keio can be distinguished from the similarly sized E. turriseiffelii by the total number crossbar terminations per specimen (V-9). Eiffellithus turriseiffelii averages 3.2 terminations/specimen while E. keio averages 9.7 terminations $/$ specimen $\left(\mathrm{p}_{\text {same variance }}=0.567 ; \mathrm{p}_{\text {same }}\right.$ mean $\left.=1.68 \mathrm{E}^{-45}\right)$. The relationship among these two specimens and $E$. casulus with respect to cross terminations (V-9) and coccolith length (V-1) is shown in Figure 10a.

Perch-Nielsen's tentative Early Cretaceous lineage (1985, Figure 12) was similar to that of Watkins and Bergen, though some inconsistencies are noted: Eiffellithus sp. 2 was illustrated with an uninterrupted upper Albian- Maastrichtian range; however, this form represents at least two distinct periods of transitional, 'intermediate' morphotypes, where the mid-line of the larger cross-bar lies $20^{\circ}-44^{\circ}$ from the longitudinal axis of the ellipse (V-9). Eiffellithus sp.2 was formally described by Watkins and Bergen (2003) as Albian species E. vonsalisiae, an intermediately orientated form between the axial cross of E. monechiae and the diagonal cross of E. casulus. After the LAD of E. vonsalisiae below the Albian-Cenomanian boundary, only symmetrical, diagonal eiffellithids are present until the upper Cenomanian. 

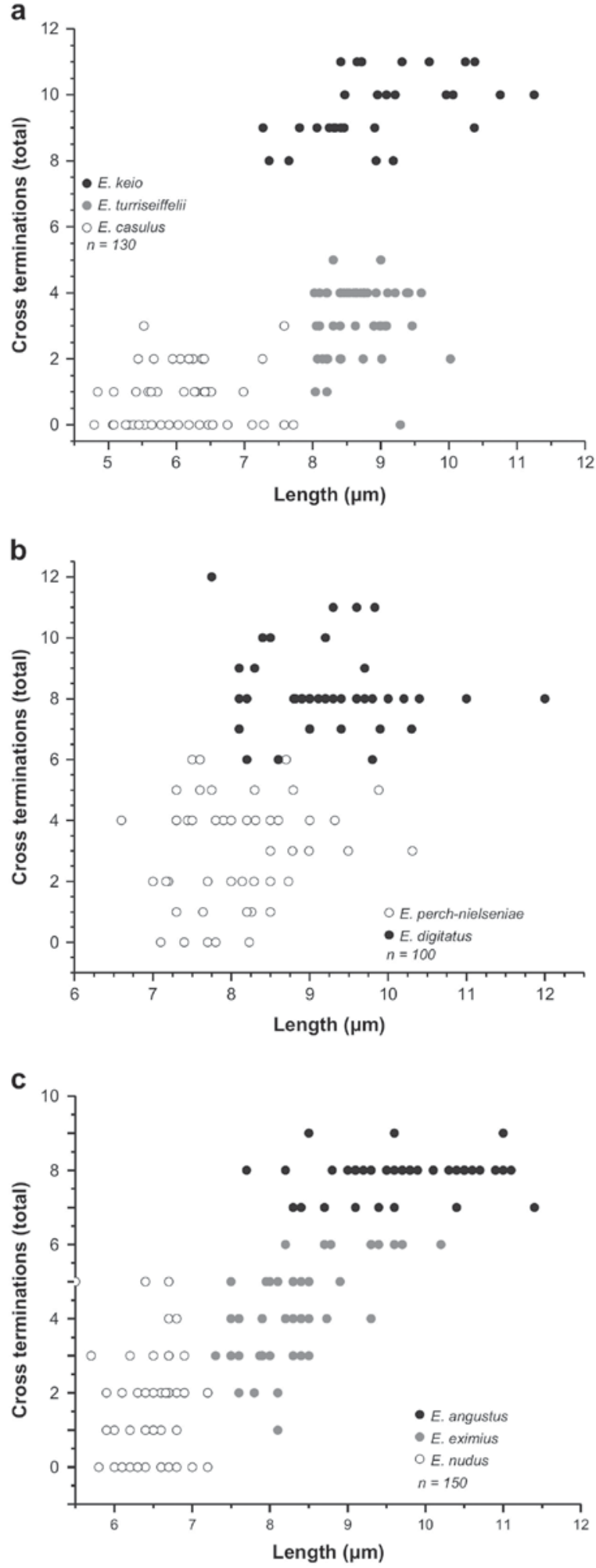

Figure 10. a-c. Graphs showing the morphological relationships among species with respect to length of the coccolith (x-axis) and total number of cross-bar terminations (y-axis). Species are grouped by angular orientation. A: Diagonal central cross $\left(45^{\circ}-60^{\circ}\right)$. B: Intermediate central cross $\left(20^{\circ}-44^{\circ}\right)$. C: Axial central cross $\left(<20^{\circ}\right)$. Groupings show the expected range of each species with respect to these morphological criteria. Species with overlapping morphological ranges can be differentiated by the location of the terminations about the cross. E. perchnielseniae very rarely shows bifurcation along the transverse arms while E. digitatus is bifurcate to trifurcate along this axis ( $\mathrm{n}=50$ for all species except for E. keio where $\mathrm{n}=30$ ).
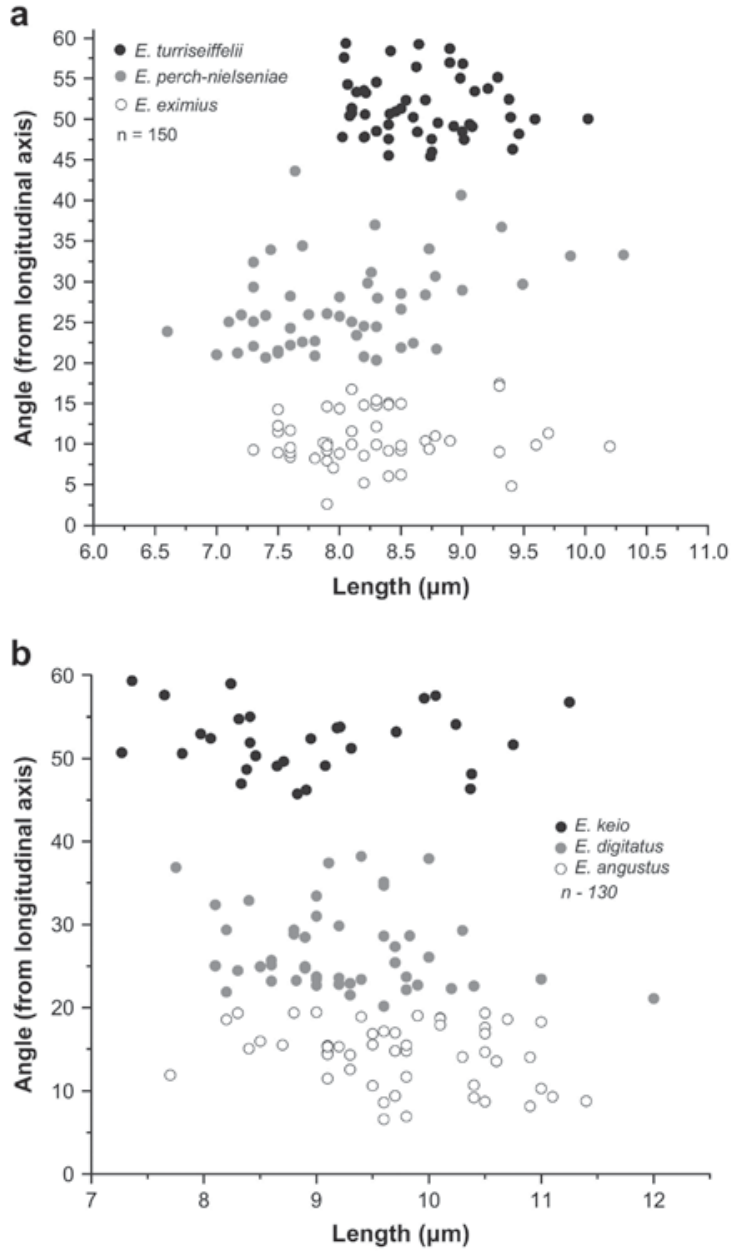

Figure 11. a-b. Graphs showing the morphological relationships among species of Eiffellithus with respect to length of the coccolith (xaxis) and the angle between the midline of the larger cross-bar and the longitudinal axis of the ellipse (y-axis). Species are grouped by crossbar terminal morphology. A: Pointed to blunt, 'simple' cross-bar termination. B: Bifurcate to trifurcate, 'ornate' cross-bar terminations. In E. turriseiffelii and E. keio $\left(45^{\circ}-60^{\circ}\right)$ all arms are approximately the same distance from the longitudinal axis so measurements represent the average angle of two of the four cross arms. Groupings show the expected range of each species with respect to these morphological criteria $\left(n=50\right.$ for each species, $\left.n_{\text {total }}=150\right)$.

Two new intermediate forms appear after this distinct break: E. perch-nielseniae n.sp. (FAD 93.9 Ma) and E. digitatus n.sp. (FAD 93.6 Ma), just below the CenomanianTuronian boundary. These 'intermediates', as with E. vonsalisiae, are transitional forms between a diagonal cross and an axial cross, though each belongs to a discrete lineage (Figure 9) with specific derived characteristics. In both forms the crossbar lengths, widths, and distal morphologies are quite variable, showing essentially no symmetry about either axis. The longitudinal cross-bar is aligned $20^{\circ}-44^{\circ}$ from the long axis of the coccolith (Figure 8), though specimens $40^{\circ}-44^{\circ}$ are infrequent (Figure 11a, b). Intermediate forms can be difficult to distinguish under cross-polarized light. The alternating birefringence of crystal elements allows the cross to appear near symmetrical at some orientations, similar to the birefringence patterns of E. praestigium. The asymmetry of intermediate forms is clearly visible when viewed in phase contrast or plane-polarized light: cross-bars nearer the longitudinal axis increase in size but decrease slightly along the transverse axis. 


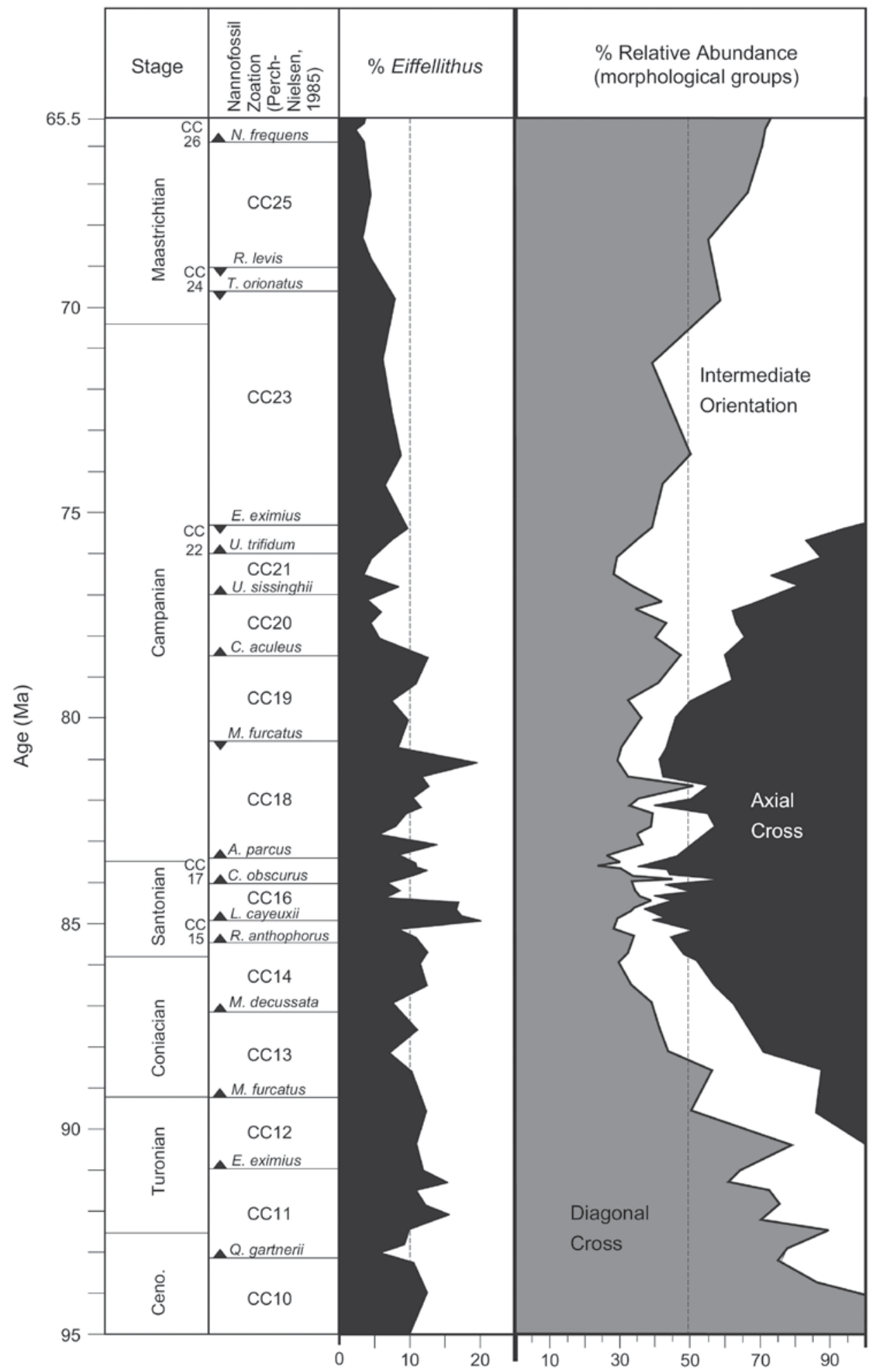

Figure 12. Relative abundance of Eiffellithus in the nannofossil community and of grouped morphotypes within the genus. The genus reaches max relative abundance of $>15-20 \%$ in the Santonian. Within the genus, species are grouped as shown in Figure 8 . Large abundance shifts within the genus are marked by the appearance of intermediate forms and again by the appearance of axial forms. Intermediate forms regain dominance in the mid-Campanian with the extinction of axial species, but slowly decline through the upper Campanian and Maastrichtian. $\mathrm{n}=66$.

These intermediate specimens can be statistically separated into two distinct populations (Figure 10b). Eiffellithus perch-nielseniae averages 3.2 terminations/specimen while E. digitatus has a mean of 8.1 terminations/specimen $\left(\mathrm{p}_{\text {same vari- }}\right.$ ance $\left.=7.71 \mathrm{E}^{-2}, \mathrm{p}_{\text {same mean }}=6.86 \mathrm{E}^{-24}\right)$. The central cross of $E$. digitatus is a continuation of the structural changes of E. keio, and this branching morphology can be seen in plane- and crosspolarized light, though best observed in phase contrast or with a one-quarter $\lambda$ mica plates. As with its ancestor E. keio (Figure 9), all cross-bars of E. digitatus show evidence of bifurcation or trifurcation. In E. turriseiffelii all cross-bars are morphologically uniform, while in the transitional E. perch-nielseniae 
the longitudinal pair can be distinguished from the transverse pair by their increase length (V- 4), width (V-5), and distal bifurcation (V-7, 9). Longitudinal cross-bars can broaden outward, while those near the transverse axis remain small and retain a tapered shape with pointed to blunt terminations.

The structure of the cross is key in the derivation of lineages. The central cross of E. eximius, and its ancestors E. perchnielseniae and E. turriseiffelii, (Figure 9) is composed of four 'triangular-shaped' optical units, while the central cross in the E. keio lineage, as noted by Bukry (1969), is composed of four " $\mathrm{C}$ "-shaped optical units. Each " $\mathrm{C}$ "-shaped crystals builds one half of two adjacent cross-bars (Figure 14E-1). This morphological development can be seen in E. digitatus, where crossbars with strong crystal boundaries act as separate optical units that curve near the center to joint the adjacent cross-bar, creating a distinct " $\mathrm{C}$ "-shape. Specimens of E. perch-nielseniae can also show longitudinal cross-bar bifurcation, but the crossbar is optically uniform. The orientation of cross-bars with trifurcate morphology can be obscured by the stacked and overlapping nature of the crystal laths, but the tips generally show alternating birefringence across well-expressed sutures when specimens are rotated. This optical division is masked in poorly developed specimens. If one of these " $\mathrm{C}$ "-shaped crystals is reduced, a thin unit with opposite optical orientation can often be seen "pinching-out" near the adjacent cross-bar.

Eiffellithus perch-nielseniae includes specimens intermediate to E. turriseiffelii and E. eximius (Figure 11a). Through time, the cross-bars continue toward the longitudinal axis until the structure no longer appears as an intermediate, but rather an axial cross. Specimens are classified as E. eximius when the mid-line of the longitudinal cross-bar is $<20^{\circ}$ from the long axis of the ellipse (Figure 8). These specimens can be statistically separated into two distinct populations, where the mean angular orientation (V-10) of E. perch-nielseniae $=27^{\circ}$, while the mean orientation of E. eximius $=11^{\circ}\left(\mathrm{p}_{\text {same variance }}=3.7 \mathrm{E}^{-4}\right.$, $\mathrm{p}_{\text {same mean }}=9.2 \mathrm{E}^{-29}$ ). The central cross of E. eximius approaches two-fold symmetry, though it remains mildly asymmetrical with respect to some morphological variables.

The interspecies variability of the axial E. eximius is much greater than observed in the diagonal E. turriseiffelii and E. casulus. Variability is more easily defined in diagonal forms, which show four-fold symmetry of the cross-bars and attachment to the rim at relatively consistent plate boundaries. In axial forms there are two distinct pairs of cross-bars: those near the longitudinal axis and those near the transverse axis. Both pairs show a fair degree of variability with respect to length and width (V- 4, $5)$, though distal cross-bar morphology varies most in the longitudinal pair (V-7). As the cross-bars extend into the tightest angle of the ellipse, they intersect with the polygonal plates filling the rim, resulting in some bifurcation in nearly all specimens.

As in the transition of the intermediate E. perch-nielseniae to the axial E. eximius, E. digitatus gives rise to E. angustus Bukry, 1969, the second Late Cretaceous axial form to evolve from a discrete diagonal ancestor (Figure 9). Eiffellithus angustus first appears in the Coniacian (CC14), when the cross-bars lie within $20^{\circ}$ of the longitudinal axis (V-10), and can be statistically distinguished from $E$. digitatus (Figure 11b): mean orientation of E. angustus $=14^{\circ}$, mean orientation of E. digita$t u s=26.9^{\circ}\left(\mathrm{p}_{\text {same variance }}=0.092, \mathrm{p}_{\text {same mean }}=1.58 \mathrm{E}^{-26}\right)$. As with its parent form, E. angustus shows the derived bifurcation at all cross-bar terminations, and the four "C-shaped" crystals described above are fully developed. At $\geq 14 \mu \mathrm{m}$ in length $E$. angustus is the largest of all axial forms.

The final axial form, E. nudus n. sp., also appears in the Coniacian (CC14), though its origin is slightly unclear. Eiffellithus nudus is the smallest axial form and shows the least interspecies variation. The average length of $E$. nudus is $6.4 \mu \mathrm{m}\left(\max _{\mathrm{L}}\right.$ $\leq 7.2 \mu \mathrm{m}$ ) while the average length of E. eximius is $8.3 \mu \mathrm{m}$ ( $\mathrm{p}_{\text {same }}$ $\left.=6.8 \mathrm{E}^{-4}, \mathrm{p}_{\text {same mean }}=1.03 \mathrm{E}^{-33}\right)$. Eiffellithus nudus avervarianc 1.5 cross-bar terminations/specimen, while the more variable E. eximius has a mean of 4.4 terminations/specimen $\left(\mathrm{p}_{\text {same }}\right.$ variance $=0.338, \mathrm{p}_{\text {same }}=6.09 \mathrm{E}^{-21}$ ). Eiffellithus nudus can be separated in a similar manner from $E$. angustus, which is even larger and more bifurcate than E. eximius. Figure 10c shows the relationship among these three axial species with respect to size (V1) and terminal cross-bar morphology (V-9). Eiffellithus nudus likely originates from E. casulus, the smallest diagonal species, by rotation of the diagonal cross to an axial position (Figure 9), and would be the third iteration in the L. Cretaceous. Eiffellithus casulus and E. nudus show the lowest interspecies variability when compared to other forms. The cross-bars frequently taper to a pointed or blunt terminal morphology (Figure 5) and the central-area appears fully infilled. Eiffellithus nudus may be a daughter of E. eximius, however this would require a decrease in size at a time of general size increase, as well as a decrease in variability. Such considerations make it more parsimonious that $E$. nudus arises from E. casulus. The three axial forms dominate the genus in the Coniacian-Early Campanian, with relative abundances $\geq 60 \%$ (Figure 12) until all go extinct by the Late Campanian. During this decline, new intermediate and diagonal species evolve to replace these axial forms.

Eiffellithus phantasma n.sp. first appears in the mid-Campanian (CC20), and rapidly dominates the Eiffellithus assemblage. This species is intermediately oriented $\left(20^{\circ}-44^{\circ}\right)$ and thinly constructed. This form likely originates from E. turriseiffelii, given the size of the coccolith and central cross construction (Figure 9). Eiffellithus parallelus Perch-Nielsen, 1973 evolves from E. phantasma through an increase in plate thickness, rotation of the central cross back toward $45^{\circ}$, and division of the cross bars down their length. Though evolution is slow, transitional specimens of E. parallelus bear the distinct cross and large central opening that characterize this species, but are weakly calcified and asymmetrical, as in E. parallelus.

One final cosmopolitan species, E. gorkiae Reinhardt, 1965 is described from the Maastrichtian. E. gorkiae is characterized by an infilled rim and a stem base with essentially no free length to the cross-bars, giving a nearly cubic outline to the central structure. Specimens that fit the original description of this species are identified by some nannofossil workers much earlier in the stratigraphic column. Structurally, E. gorkiae is akin to E. turriseiffelii and E. casulus, but with no free-length to the "cross-bars" of the central cross. This form likely arises from E. casulus by a reduction in the cross-bar length, with specimens becoming larger up-section. All Maastrichtian members of the genus (Figure 9) disappear near or across the K/P boundary with $95-99 \%$ of the nannofossil assemblage. The morphological characteristics of the species discussed above are summarized in Table 1.

\section{Biostratigraphy}

Key characteristics such as resistance to dissolution, high abundance, cosmopolitan distribution, and rapid rates of evolution make species of Eiffellithus excellent candidates as biostratigraphic datums. Currently both E. turriseiffelii and E. eximius are biostratigraphic markers in multiple nannofossil zonation schemes. The first occurrence of E. turriseffelii is the primary marker for the base of nannofossil zones CC9 of Perch-Nielsen (1985), NC10 of Roth (1978) and UC0 of Burnett and Whitham (1999). As shown by Watkins and Bergen (2003), the first appearance of the smaller E. casulus occurs at $100.5 \mathrm{Ma}$, approxi- 
Table 1.

\begin{tabular}{|c|c|c|c|c|c|c|c|c|c|c|c|}
\hline \multicolumn{2}{|l|}{ Morphological characteristics } & $\begin{array}{l}\text { E. } \\
\text { ustus }\end{array}$ & $\begin{array}{c}\mathrm{E} . \\
\text { casulus }\end{array}$ & $\begin{array}{c}\mathrm{E} . \\
\text { digitatus }\end{array}$ & $\begin{array}{c}\text { E. } \\
\text { eximius }\end{array}$ & $\begin{array}{c}\mathrm{E} . \\
\text { keio }\end{array}$ & $\begin{array}{c}E . \\
\text { nudus }\end{array}$ & $\begin{array}{l}\text { E. perch- } \\
\text { nielseniae }\end{array}$ & $\begin{array}{c}\mathrm{E} . \\
\text { parallelus }\end{array}$ & $\begin{array}{c}\text { E. } \\
\text { phantasma }\end{array}$ & $\begin{array}{c}\text { E. } \\
\text { turriseiffelii }\end{array}$ \\
\hline Coccolith length (1) & $\begin{array}{l}\text { small }(<5 \mu \mathrm{m}) \\
\text { medium }(5-8 \mu \mathrm{m}) \\
\text { large }(8-12 \mu \mathrm{m}) \\
\text { very large }(>12 \mu \mathrm{m})\end{array}$ & - & $\bullet$ & $\bullet$ & $\bullet$ & $\bullet$ & $\bullet$ & $\bullet$ & $\bullet$ & $\bullet$ & $\bullet$ \\
\hline Eccentricity/Axial ratio (3) & $\begin{array}{l}\text { broad }(1.1-1.2) \\
\text { normal }(1.3-1.4) \\
\text { narrow }(1.5-1.7)\end{array}$ & $\bullet$ & • & $\bullet$ & $\bullet$ & $\bullet$ & $\bullet$ & $\bullet$ & $\bullet$ & $\bullet$ & $\bullet$ \\
\hline Angular orientation (10) & $\begin{array}{l}\text { axial }\left(>20^{\circ}\right) \\
\text { intermediate }\left(20^{\circ}-44^{\circ}\right) \\
\text { diagonal }\left(45^{\circ}-60^{\circ}\right)\end{array}$ & $\bullet$ & $\bullet$ & $\bullet$ & $\bullet$ & $\bullet$ & $\bullet$ & - & & $\bullet$ & $\bullet$ \\
\hline Cross-bar ratio (6) & $\begin{array}{l}\text { equant }(\sim 1.0) \\
\text { asymmetrical }(1.11-.25) \\
\text { elongate }(>1.25)\end{array}$ & $\bullet$ & $\bullet$ & $\bullet$ & • & $\bullet$ & $\bullet$ & : & $\bullet$ & $\bullet$ & $\bullet$ \\
\hline $\begin{array}{l}\text { Cross-bar terminal } \\
\text { morphology (7-9) }\end{array}$ & $\begin{array}{l}\text { pointed to blunt } \\
\text { forked } \\
\text { bifurcate } \\
\text { trifurcate }\end{array}$ & • & $\bullet$ & $\bullet$ & $\begin{array}{l}\bullet \\
\bullet \\
\bullet\end{array}$ & $\bullet$ & $\bullet$ & • & $\bullet$ & $\bullet$ & $\bullet$ \\
\hline Cross-bar suture & $\begin{array}{l}\text { weak } \\
\text { prominent }\end{array}$ & $\bullet$ & $\bullet$ & $\bullet$ & - & $\bullet$ & $\bullet$ & $\bullet$ & $\bullet$ & $\bullet$ & $\bullet$ \\
\hline Central stem height & $\begin{array}{l}\text { confocal } \\
\text { weakly confocal } \\
\text { vaulted }\end{array}$ & $\bullet$ & $\bullet$ & $\bullet$ & $\bullet$ & $\bullet$ & $\bullet$ & $\bullet$ & $\bullet$ & $\bullet$ & $\bullet$ \\
\hline
\end{tabular}

mately 0.6 m.y. before the FAD of E. turriseiffelii (99.9 Ma). Further work in this study shows that these two morphotypes are distinct populations (Figure 7 and Figure 10a). As a result, these biostratigraphic datums must be redefined by either changing the marker to E. casulus or by moving the base of the zone up $\sim 0.6$ m.y. to the first appearance of the large morphotype (> $8 \mu \mathrm{m}$ ), E. turriseiffelii (Figure 9). An alternate option is to expand resolution by using both markers in a subzone scheme.

The FAD of E. eximius is the current marker for the base of nannofossil zones CC12, NC15, and UC8, but can be unreliable due to the poor understanding of the morphological variation in the axial species complex. This study has shown that E. eximius evolves in the Turonian, and is the first Upper Cretaceous axial form to appear in the genus, by the continued rotation of E. perch-nielseniae to $<20^{\circ}$ from the longitudinal axis (Figure 9). Eiffellithus angustus does not appear until the Coniacian (CC14), as shown at two separate localities: ODP 171b-1050C, above Core 20-2, and the Niobrara Chalk at Loc. 1, $11 \mathrm{~m}$. If the datum is restricted to the FAD of specimens that are of simple construction, aligned within $20^{\circ}$ of the longitudinal axis, and with pointed to blunt cross-bar terminations, E. eximius should yield a fairly reliable biostratigraphic marker.

The current primary biostratigraphic datum for the base of CC23 and UC16 is the LAD of E. eximius, which corresponds to the LAD of all axial morphotypes of Eiffellithus. Based on the refined taxonomy of the E. eximius complex in this study, the last axial species is not E. eximius, but rather E. angustus. All axial forms rapidly decline through the Campanian (Figure 12), with the LAD of E. nudus and E. eximius in Sisseton Core 20, 2 $\mathrm{m}$ below the LAD of E. angustus in Sisseton Core 19. The current datums CC23 and UC16 should then be reassigned to the LAD of E. angustus, which marks the LAD of all Eiffellithus spp. with an axial cross.

The first appearance of intermediate species in the uppermost Cenomanian may provide a useful biostratigraphic datum, as this is a notable morphological change in the Eiffellithus assemblage (Figure 9). Authors have noted inverse sequencing and diachoroniety in some nannofossil datums in the Western Interior Seaway from the Cenomanian-Santonian (Bralower and Bergen, 1998; Watkins et al., 1993), so investigation of additional cores with a global distribution is needed to confirm the precise stratigraphic distribution of these new species. The FAD of E. phantasma in CC19 may also prove biostratigraphically useful, as it increases in abundance rapidly after its first appearance. Again, this should be confirmed with further research and global correlation. While individual speciation and extinction events have been highlighted here, the character if the entire Eiffellithus assemblage can also rapidly provide biostratigraphic information, as discussed below.

\section{Evolutionary patterns}

Examination of cores from the Western Atlantic shows the abundance of Eiffellithus increased from $<1 \%$ in upper Albian sediments to $\sim 8 \%$ in the lower Cenomanian (Watkins and Bergen, 2003, Figure 5). This general rise in abundance continued through much of the Upper Cretaceous, averaging $>10 \%$ through the mid-Campanian (Figure 12). Eiffellithus abundance reached a maximum in the Santonian, with levels of 15-20\% during peak species richness within the genus. Wellpreserved sediments from the lower Campanian give values similar to the Santonian, though intervals of lower abundance also occur. Abundance levels gradually declined from the mid-Campanian through Maastrichtian, averaging 5.5\%. Values dropped to $2-3 \%$ in the mid-late Maastrichtian, the lowest for the genus through the entire Late Cretaceous, overshadowed by genera such as Micula and Prediscosphaera.

There are several assemblage changes within the genus with respect to morphology: At the start of the Cenomanian, all forms of Eiffellithus bear a symmetrical diagonal cross with crossbars at $45^{\circ}-60^{\circ}$ (Figure 9). The first major morphological shift of the Late Cretaceous occurred with the FADs of $E$. perch-nielseniae and E. digitatus in the Late Cenomanian. Intermediately oriented specimens rapidly increased to $>30 \%$ of the genus in the Turonian, while the relative abundance of the genus remained at $10-12 \%$ (Figure 12).

The first appearance of axial forms in the Turonian and Coniacian (Figure 9) marks a second morphological shift. Axial forms quickly became dominant, reaching maximum abundances of $>60 \%$ in the Santonian. This peak coincides with the highest species richness and relative abundance of the genus (> 15-20\%) (Figure 12). Diagonal forms maintained fairly steady average values of $\sim 30-40 \%$, but intermediate forms seem to be replaced by axial species, reaching a low of $\leq 10 \%$ of all Eiffellithus. 
A third shift in morphological dominance occurs with the rapid decline of axial forms and the FAD of E. phantasma. These mid-Campanian events greatly increased the relative abundance of intermediates for the second time in the Late Cretaceous (Figures $9 \& 12$ ), though each peak was induced by different species. After the FAD of E. parallelus the abundance of intermediately oriented forms slowly declined and diagonal forms finally regain dominance within the genus, though the abundance of Eiffellithus in the nannofossil assemblage had been greatly reduced since these forms last dominated in the Cenomanian and Turonian (Figure 12).

In the Late Cretaceous, three axial forms arose from discrete ancestors. The statistical relationships among species with respect to size and distal morphology indicates that cross orientation is a parallel characteristic that developed independently in multiple lineages of the Upper Cretaceous (Figure 9). These axial species arose iteratively, by the continued rotation of diagonal forms through intermediate orientations, with each expressing the derived characteristics of its ancestral forms. The sequence of morphological development makes it more parsimonious to attribute the angular orientation to parallel evolution. Despite the minute size of calcareous nannofossils, these organisms are structurally unique and highly diverse. An extensive study on the patterns of evolutionary divergence and convergence across multiple genera may provide insight into structural constraints, gene flow, and speciation.

\section{Conclusions}

The calcareous nannofossil genus Eiffellithus has long been used as a biostratigraphic marker, both in paleoceanographic research and in industry-related applications. Broad interpretations of the original descriptions and varying criteria encouraged inconsistencies in species identification and biostratigraphic correlation. Detailed examination of Eiffellithus from the Upper Cretaceous indicates a more taxonomically diverse assemblage then heretofore noted. Quantitative and semi-quantitative morphological analysis of $\sim 9000$ specimens of Eiffellithus has shown at least six new Late Cretaceous species. Genetic assessment, if possible, would yield a far greater species richness than calcified morphology alone (Geisen et al., 2004; De Vargas and Probert, 2004; De Vargas et al., 2001, 2004; Renaud and Klaas, 2001).

The taxonomy of Eiffellithus has been complicated by the iterative nature of this group, with at least three distinct episodes of central cross rotation. This iterative action has been documented in numerous fossil groups (Aubry, 1988; Haas, 1942; Geary et al., 2002), but was obscured by the relatively simple morphology of these microfossils. Detailed stratigraphic investigation has clarified a number of inconsistencies within current Eiffellithus biostratigraphic datums, and suggests potential steps to reconcile these issues.

Finally, morphological turnovers within the genus show distinct changes in dominance, where each turnover is related to a period of extinction and/or diversification. These morphological shifts may be related to paleoenvironmental changes during the Late Cretaceous (Bollmann et al., 1998; Norris, 1991). The most striking morphological turnover and increase in relative abundance of Eiffellithus occurs during the Turonian-Santonian, with the iterative appearance of at least three species of axial Eiffellithus. This diversification may be related to changes in environmental determinants such as sealevel, surface water temperatures, nutrient availability, and water stratification. Such events are seen in several microfossil taxa through time (Aubry, 1988; Cifelli, 1969) and highlights the need for further discussion and collaboration on such top- ics within the microfossil community. This type of community study, however, requires a better understanding of nannofossil taxonomy, morphology and diversity through time.

\section{Acknowledgements}

This research used samples and data provided by the Deep Sea Drilling Program and the Ocean Drilling Program. The DSDP and ODP are sponsored by the National Science Foundation (NSF) and participating countries under the management of Joint Oceanographic Institutions (JOI) Inc. Funding for this project was provided by the Gulf Coast Section of the Society of Economic Paleontologists and Mineralogists (GC-SEPM) Ed Picou Fellowship. The authors would also wish to thank Mary Anne Holmes, Tracy Frank, and Jens Schmieder (University of Nebraska-Lincoln) for their revisions and suggestions, which greatly improved this manuscript.

\section{References}

Aubry, $1988 \varangle$ M. P. Aubry, Phylogeny of the Cenozoic calcareous nannoplankton genus Helicosphaera, Paleobiology 14 (1) (1988), pp. 64-80.

Bollmann et al., $1998 \varangle$ J. Bollmann, K. H. Baumann and H. R. Thierstein, Global dominance of Gephyrocapsa coccoliths in the late Pleistocene: selective dissolution, evolution, or global environmental change, Paleoceanography 13 (5) (1998), pp. 517-529.

Bralower and Bergen, $1998<\mathrm{T}$. J. Bralower and J. A. Bergen, Cenomanian-Santonian calcareous nannofossil biostratigraphy of a transect of cores drilled across the Western Interior Seaway. In: W. E. Dean and M. A. Arthur, Editors, Stratigraphy and Paleoenvironments of the Cretaceous Western Interior Seaway, USA vol. 6, Society for Economic Paleontology and Mineralogy Concepts in Sedimentology and Paleontology (1998), pp. 159-177.

Bukry, $1969 \triangleleft$ D. Bukry, Upper Cretaceous Nannofossils from Texas and Europe vol. 51, University of Kansas Paleontology Contributions (1969) pp. $79,40 \mathrm{pl}$.

Burnett and Whitham, $19994 \mathrm{~J}$. A. Burnett and F. Whitham, UC nannofossil zonation In: J. A. Burnett, Upper Cretaceous, Chapter 6. In: P. R. Bown, Editor, Calcareous Nannofossil Biostratigraphy, Kluwer Academic Publishing, Cambridge University Press, Cambridge (1999), pp. 132-199.

Cifelli, $19694 \mathrm{R}$. Cifelli, Radiation of Cenozoic planktonic foraminifera, Systematic Zoology 18 (2) (1969), pp. 154-168.

Crux, $1991-$ J. A. Crux, Albian calcareous nannofossil from the Gault Clay of Munday's Hill (Bedfordshire, England), Journal of Micropaleontology 10 (1991), pp. 203-222.

Deflandre and Fert, $1954 \varangle$ G. Deflandre and C. Fert, Observations sur les coccolithophorides actuels et fossiles en microscopie ordinarie et electronique, Annales de Paleontologie 40 (1954), p. 6817 pl.

De Vargas and Probert, 20044 C. De Vargas and I. Probert, New keys to the past: Current and future DNA studies in Coccolithophores, Micropaleontology 50 (Suppl. 1) (2004), pp. 45-54.

De Vargas et al., 2004 C. De Vargas, A. G. Sáez, L. K. Medlin and H. R. Thierstein In: H. R. Thierstein and J. R. Young, Editors, Coccolithophores, from Molecular Processes to Global Impact Super-Species in the Calcareous Plankton, Springer-Verlag, New York (2004), pp. 271-298.

De Vargas et al., 20014 C. De Vargas, S. Renaud, H. Hilbrecht and J. Pawlowski, Pleistocene adaptive radiation in Globorotalia truncatulinoides: genetic, morphologic, and environmental evidence, Paleobiology 27 (1) (2001), pp. 104-125.

Gartner, 1968 S. Gartner Jr., Coccoliths and Related Calcareous Nannofossil from Upper Cretaceous Deposits of Texas and Arkansas vol. 48, University of Kansas Paleontological Contributions (1968) pp. 56.

Geary et al., $2002<$ D. H. Geary, A. W. Staley, P. Müller and I. Magyar, Iterative changes in Lake Pannon Melanopsis reflects a recurrent theme in gastropod morphological evolution, Paleobiology 28 (2) (2002), pp. 208-221.

Geisen et al., $2004 \varangle$ M. Geisen, J. R. Young, I. Probert, A. G. Sáez and K. H. Baumann et al., Species level variation in coccolihophores. In: H. R. Thierstein and J. R. Young, Editors, Coccolithophores from Molecular Process to Global Impact, Springer-Verlag, Berlin Heidelberg (2004), pp. 327-366.

Geisen et al., 19994 M. Geisen, J. Bollman, J. O. Herrle, J. Mutterlose and J. R. Young, Calibration of the random settling technique for calculation of absolute abundances of calcareous nannoplankton, Micropaleontology 45 (1999), pp. 437-442.

Haas, $1942 \varangle$ O. Haas, Recurrance of morphologic types and evolutionary cycles in Mesozoic ammonites, Journal of Paleontology 16 (1942), pp. 643-650. 
Hattin, 1975 D. E. Hattin, Stratigraphy and depositional environments of the Greenhorn Limestone (Upper Cretaceous) of Kansas, Kansas Geological Survey Bulletin 209 (1975), pp. 1-128.

Hattin, 1982 D. E. Hattin, Stratigraphy and depositional environments of the Smoky Hill Chalk Member, Niobrara Chalk (Upper Cretaceous) of the type area, western Kansas, Kansas Geological Survey Bulletin 225 (1982), pp. 1-108

Hibbard, 1976 D. J. Hibbard, The ultrastructure and taxonomy of the Chrysophyceae and Prymnesiophyceae (Haptophyceae): a survey with some new observations on the ultrastructure of the Chrysophyceae, Botanical Journal of the Linnaen Society 72 (1976), pp. 55-80.

Hill, 19764 M. E. Hill III, Lower Cretaceous calcareous nannofossils from Texas and Oklahoma, Palaeontographica (B) 156 (1976), pp. 103-179.

Hill and Bralower, 1987 M. E. Hill III and T. Bralower, Early evolution, stratigraphy, and taxonomy of Eiffellithus eximius and closely related species. In: H. Stradner and K. Perch-Nielsen, Editors, Proceedings (Vienna, Austria): Abhandlungen der Geologischen Bundesanstalt vol. 39, International Nannoplankton Association (1987), pp. 89-97 2 pl.

Hammer et al., 2001 Ø. Hammer, D. A. T. Harper and P. D. Ryan, PAST: Paleontological Statistics Software Package for Educators and Data Analysis, Palaeontologia Electronica 4 (2001), p. 9

Hanczaryk and Gallagher, 2007 P. A. Hanczaryk and W. B. Gallagher, Stratigraphy and paleoecology of the Pierre Shale along the Missouri River, central South Dakota. In: J. E. Martin and D. C. Parris, Editors, The Geology and Paleoecology of the Late Cretaceous Marine Deposits of the Dakotas, Geological Society of America Special Paper 427 (2007), pp. 51-70.

Manivit, 1971 Manivit, H., 1971. Nannofossiles calcaires du crétacé français (Aptiene-Maastrichtien). Essai de biozonation appuyée sur les stratotypes. Doctoral thesis, Université de Paris, 387 pp.

Norris, 19914 R. D. Norris, Biased extinction and evolutionary trends, $\mathrm{Pa}$ leobiology 17 (4) (1991), pp. 388-399.

Perch-Nielsen, 1968 K. Perch-Nielsen, Der feinbau und die klassifikation der coccolithen aus dem Maastrichtien von Dänemark, Det Kongelige Danske Videnskabernes Selskab Biologiske Skrifter 16 (1) (1968), pp. 1-94.

Perch-Nielsen, $1973 \varangle$ K. Perch-Nielsen, Neue coccolithen aus dem Maastrichtian von Dänemark, Madagaskar und Ägypten, Geological Society of Denmark Bulletin 22 (1973), pp. 306-333 10 pl.

Perch-Nielsen, $1979 \varangle$ K. Perch-Nielsen, Calcareous nannofossils from the Cretaceous between the North Sea and the Mediterranean. In: J. Wiedmann, Editor, Aspekte der Kreide Europas, International Union of Geological Science Series A (1979), pp. 223-272.

Perch-Nielsen, 1985 K. Perch-Nielsen, Mesozoic calcareous nannofossils. In: H. M. Bolli, J. B. Saunders and K. Perch-Nielsen, Editors, Plankton Stratigraphy, Cambridge University Press, Cambridge (1985), pp. 329-426.

Rasband, 1997-2006 W. S. Rasband, ImageJ. U. S, National Institutes of Health, Bethesda, Maryland, USA (1997-2006); online at http://rsb.info. nih.gov/ij/

Reinhardt, $1965 \varangle$ P. Reinhardt, Neue familien fur fossile kalkflagellaten (Coccolithophoriden, Coccolithineen), Monatsberichte der Deutschen Akademie der Wissenschaften zu Berlin 7 (1965), pp. 30-40 3pl.

Renaud and Klaas, $2001 \varangle$ S. Renaud and C. Klaas, Seasonal variations in the morphology of the coccolothophore Calcidiscus leptoporus off Bermuda (N. Atlantic), Journal of Plankton Research 23 (8) (2001), pp. 779-795.

Rood, 1971 A. P. Rood, W. W. Hay and T. Barnard, Electron microscope studies of Oxford Clay coccoliths, Eclogae Geologicae Helvetiae 64 (1971), pp. 245-271.

Roth, 1978 P. H. Roth et al., Cretaceous nannoplankton biostratigraphy and oceanography of the Northwestern Atlantic Ocean. In: W. E. Benson and R. E. Sheridan, Editors, Initial Reports of the Deep Sea Drilling Project Volume XLIV, United Stated Government Printing Office, Washington, D. C (1978), pp. 731-759.

Sageman et al., $1998 \backsim$ B. B. Sageman, J. Rich, M. A. Arthur, W. E. Dean, C. E. Savrda and T. J. Bralower, Multiple milankovitch cycles in the bridge creek limestone (Cenomanian-Turonian), western interior basin. In: W. E. Dean and M. A. Arthur, Editors, Stratigraphy and Paleoenvironments of the Cretaceous Western Interior Seaway, USA vol. 6, Society for Economic Paleontology and Mineralogy Concepts in Sedimentology and Paleontology (1998), pp. 153-171.

Schultz et al., $1980 \backsim$ L. G. Schultz, H. A. Tourtelot, J. R. Gill and J. G. Boerngen, Composition and properties of the Pierre Shale and equivalent rocks, northern Great Plains Region, United States Geological Survey Professional Paper 1064-B (1980), p. 84.

Shamrock and Watkins, 2008 J. L. Shamrock and D. K. Watkins, World Data Center-A, Colorado, USA, Boulder (2008); online at http://www. ncdc.noaa.gov/paleo/data.html

Shipboard Scientific Party, 1998 Shipboard Scientific Party et al., Sites 1049 and 1050. In: R. D. Norris, D. Kroon and A. Klaus, Editors, Pro- ceedings of the Ocean Drilling Program Initial Reports Volume 171B, Ocean Drilling Program, College Station, Texas (1998), pp. 47-91.

Stover, $1966<$ L. E. Stover, Cretaceous coccoliths and associated nannofossil from France and the Netherlands, Micropaleontology 12 (1966), pp. 133-166

Thierstein, $1980 \varangle$ H. R. Thierstein, Selective dissolution of Late Cretaceous and earliest Tertiary calcareous nannofossils; experimental evidence, Cretaceous Research 1 (1980), pp. 165-176.

Verbeek, 1977 J. W. Verbeek, Calcareous nannoplankton biostratigraphy of Middle and Upper Cretaceous deposits in Tunisia, southern Spain and France, Utrecht Micropaleontological Bulletin 16 (1977), pp. 1-157 12pl.

Watkins and Bergen, 2003 D. K. Watkins and J. A. Bergen, Late Albian adaptive radiation in the calcareous nannofossil genus Eiffellithus, $M i$ cropaleontology 49 (2003), pp. 231-252.

Watkins et al., 1993 D. K. Watkins, T. J. Bralower, J. M. Covington and C. G. Fisher, Biostratigraphy and paleoecology of the Upper Cretaceous calcareous nannofossils in the Western Interior Basin, North America. In: W. G. E. Caldwell and E. G. Kauffman, Editors, Evolution of the Western Interior Basin, Geological Association of Canada Special Paper 39 (1993), pp. 521-537

Worzel et al., $1973<\mathrm{J}$. L. Worzel and W. Bryant et al., Initial Reports of the Deep Sea Drilling Project, Volume X, United States Government Printing Office, Washington D. C. (1973) 748.

Young et al., 19974 J. R. Young, J. A. Bergen, P. A. Bown, J. A. Burnett, A. Fiorentino, R. W. Jordan, A. Kleijne, B. E. Van Niel, A. J. T. Romein and K. von Salis, Guidelines for coccolith and calcareous nannofossil terminology, Palaeontology 40 (pt. 4) (1997), pp. 875-912.

\section{Appendix 1. Systematic Paleontology}

All figured specimens and type species have been deposited in the Micropaleontology Collection at the University of Nebraska-Lincoln. Species descriptions use terms recommended by the "Guidelines for coccolith and calcareous nannofossil terminology" (Young et al., 1997).

Class PRYMNESIOPHYCEAE (Hibbard, 1976)

Order PRYMNESIOPHYCIDAE (Rood et al., 1971)

Family EIFFELLITHALES (Reinhardt, 1965)

Genus EIFFELLITHACEAE (Reinhardt, 1965)

\section{Type species: Eiffellithus turriseiffelii Reinhardt, 1965}

Eiffellithus angustus (Bukry, 1969) amended herein Figure 14, E-G

2002 Eiffellithus eximius, (Stover) Perch-Nielsen-Hadavi, pl.1, Figure 19 1999 Eiffellithus eximius, (Stover) Perch-Nielsen-Burnett, pl. 6.4, Figure 24 1969 Eiffellithus angustus, Bukry, pl. 28, figs 10-12

1968 Eiffellithus turriseiffeli, (Deflandre) Reinhardt, Gartner, pl. 18, Figure 10; pl. 19, fig 2a-c

Amended diagnosis: Medium to very large, normally to broadly elliptical eiffellithid, with a stem base of four disjunct, "C-shaped" crystals that rise above the central-area, forming a large, diamond shaped opening through the center of the axial cross.

Amended description: Species of eiffellithid with a broadly to normally elliptical rim consisting of 40-80 steeply inclined elements, giving a smooth to serrate outline. The inner rim consists of 8-15 radially-oriented, polygonal elements that converge in the center to form an elliptical opening. This opening can be obscured by overgrowth of the central plates that fill the central-area. Rims display first order birefringence, though inner plates tend to be far brighter than the outer rim. A broad, slightly asymmetrical axial cross spans much of the centralarea. Four " $\mathrm{C}$ "-shaped crystals composed of thin, lath-like elements curve to form one-half of each adjacent cross-bar. Crystal boundaries are prominent, splitting the cross-bars down their length from the tip to the cross center. This results in an alternating pattern of birefringence across the cross-bars when rotated. Cross-bars show alternate extinction with a one-quarter $\lambda$ mica plate (Figure 17). Broad bifurcation occurs when the tips of these crystals curve around the back plates. Crossbars join in the center to form a large, diamond-shaped opening that rises above the plane of the coccolith. A large stem sits atop this elevated cross, but is rarely preserved. 

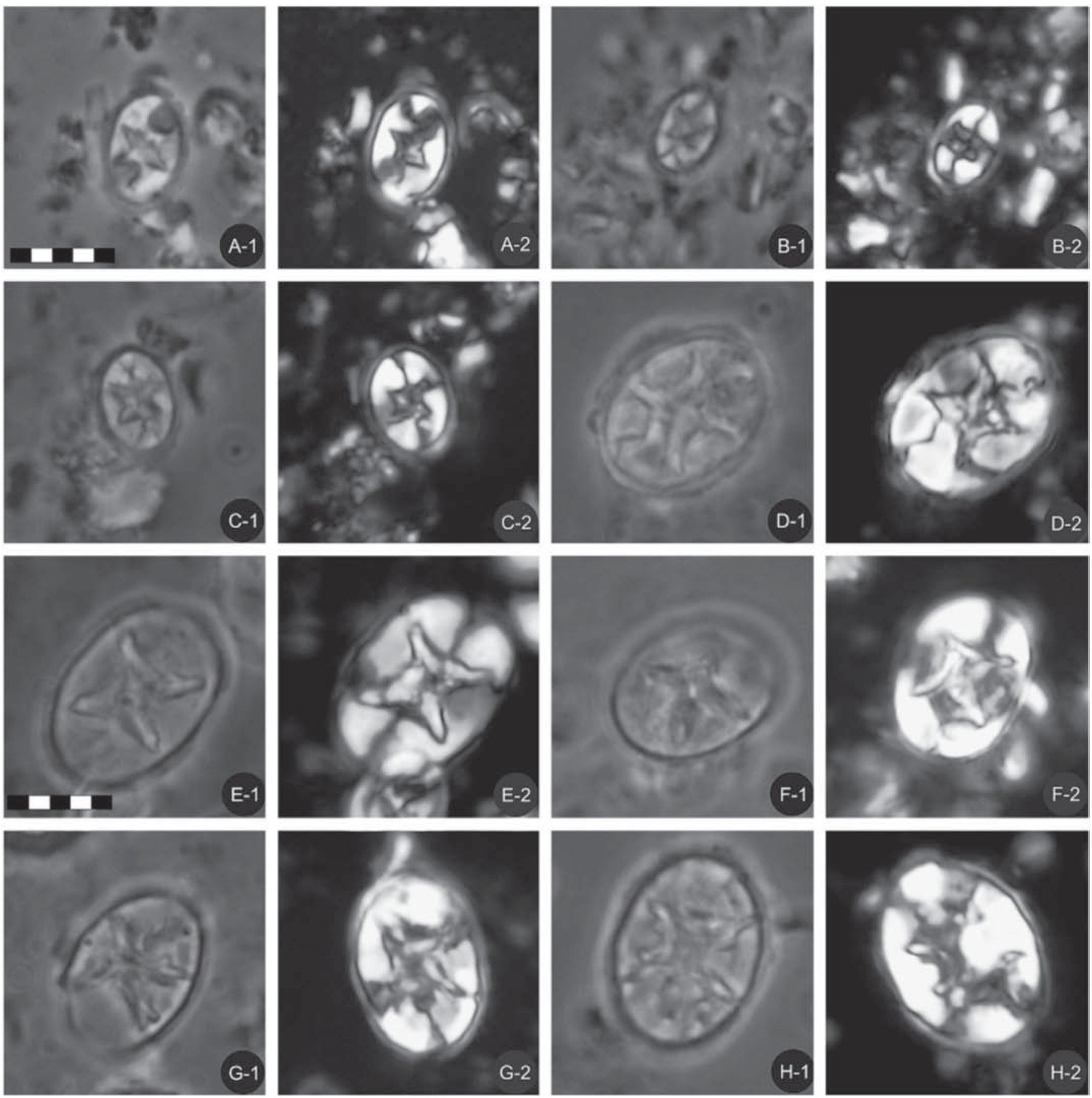

Figure 13. Light photomicrographs of selected specimens at 1250x magnification. Scale bars are $5 \mu \mathrm{m}$ with $1 \mu \mathrm{m}$ divisions. XPL $=$ cross polarized light. PC = phase contrast. A. E. casulus n.sp. (holotype), U. Cenomanian, Hartland Mbr, Greenhorn Lst, Loc. 6, 10.15 m; A-1: PC, A-2: XPL. B. E. casulus (paratype), U. Cenomanian, Hartland Mbr, Greenhorn Lst, Loc. 6, 10.25 m; B-1: PC, B-2: XPL; C. E. casulus (paratype), L. Campanian, Smokey Hill Mbr, Niobrara Chalk, Loc. 24, 11.5 m; C-1: PC, C-2: XPL. D. E. turriseiffelii (Deflandre and Fert, 1954; Reinhardt, 1965) PerchNielsen 1968, U. Cenomanian, Hartland Mbr, Greenhorn Lst, Loc. 6, 10.45 m; D-1: PC, D-2: XPL. E. E. turriseiffelii, U. Maastrichtian, ODP Leg 171b1049a-17-2-(119-126 cm); E-1: PC, E-2: XPL. F. E. turriseiffelii, mid-Campanian, Gregory Mbr, Pierre Shale, Core 19-3-(8.5 cm); F-1: PC, F-2: XPL. G. E. keio, n. sp. (paratype), U. Cenomanian, Hartland Mbr, Greenhorn Lst, Loc. 6, 10.65 m; G-1: PC, G-2: XPL. H. E. keio (paratype), L. Turonian, Hartland Mbr, Greenhorn Lst, Loc. 6, 11.45 m; H-1: PC, H-2: XPL.

Measurements:

Length $=7.4-14 \mu \mathrm{m}(\mu=9.7$, s.d. $=0.86, \mathrm{n}=50)$

Width $=5.7-9.2 \mu \mathrm{m}(\mu=7.7$, s.d. $=0.69, \mathrm{n}=50)$

Eccentricity $=1.15-1.45(\mu=1.27$, s.d. $=0.05, \mathrm{n}=50)$

Occurrence: Coniacian - upper Campanian

Remarks: Eiffellithus angustus can be distinguished from most other species of the genus by the axial orientation of the central cross, $<20^{\circ}$ from the longitudinal axis. Though originally described by Bukry (1969) this species had been absorbed into the E. eximius species-complex. Eiffellithus angustus is the largest species with an axial cross, up to $14 \mu \mathrm{m}$ in length, so can be easily distinguished from the small axial species E. nudus $\left(\max _{\mathrm{L}}=7.2 \mu \mathrm{m}\right)$. Eiffellithus angustus can be distinguished from E. eximius by a number of features: Generally, E. angustus is larger than E. eximius, though specimens of the latter 

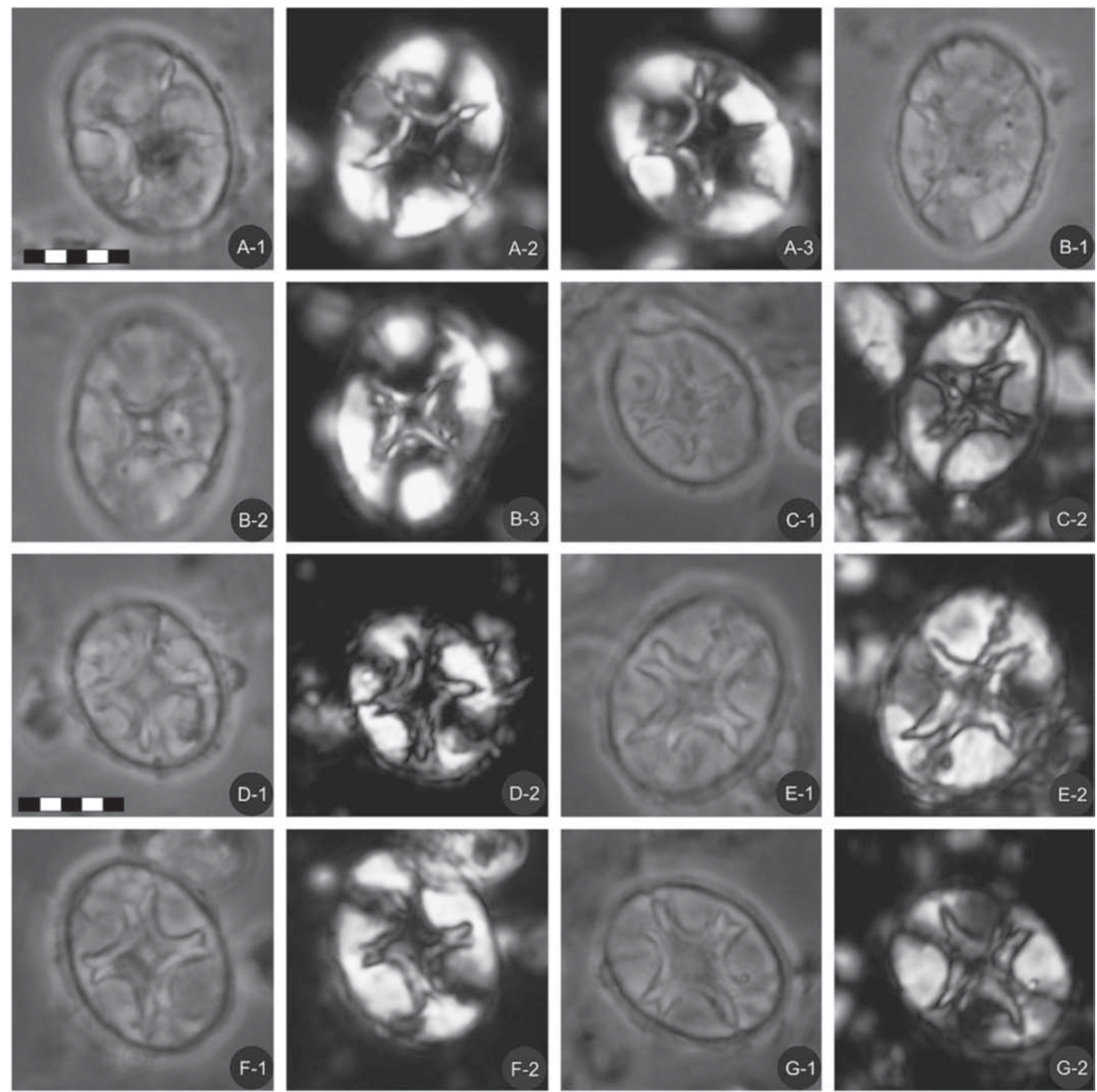

Figure 14. Light photomicrographs of selected specimens at 1250x magnification. Scale bars are $5 \mu \mathrm{m}$ with $1 \mu \mathrm{m}$ divisions. XPL $=\mathrm{cross}$ polarized light. PC = phase contrast. A. E. keio n.sp. (holotype), L. Turonian, Hartland Mbr, Greenhorn Lst, Loc. 6, 13.45 m; A-1: PC, A-2, 3: XPL. B. E. digitatus n.sp., (holotype), L. Turonian, Hartland Mbr, Greenhorn Lst, Loc. 6, 11.35 m; B-1, 2: PC, B-3: XPL C. E. digitatus (paratype), U. Santonian, DSDP Leg 10-95-17-1-(27 cm): C-1: PC, C-2: XPL. D. E. digitatus (paratype), L. Campanian, Smokey Hill Mbr, Niobrara Chalk, Loc. 25, 4.5 m; D-1: PC, D-2: XPL. E. E. angustus Bukry, 1969, M. Santonian, Smokey Hill Mbr, Niobrara Chalk, Loc. 12, 2.5 m; E-1: PC, E-2: XPL. F. E. digitatus, M. Santonian, Smokey Hill Mbr, Niobrara Chalk, Loc. 19, 16 m; F-1: PC, F-2: XPL. G. E. angustus, M. Santonian, Smokey Hill Mbr, Niobrara Chalk, Loc. $12,2.5$ m; G-1: PC, G-2: XPL.

reach lengths comparable to E. angustus; The cross-bars of E. angustus are more broad and robust, show prominent sutures along their length, and have obvious bifurcations on all four terminations. E. eximius does not show this characteristic along the transverse axis. The crystal boundaries of E. eximius are less prominent and discontinuous. The outline of the cross-bars, which are less robust, tapers away from the center of the structure in E. eximius, while they broaden in E. angustus.
Eiffellithus casulus Shamrock, $n$. sp.

Figs. 13, A-C; 17, J

1968 Eiffellithus turriseiffeli (Deflandre) Reinhardt, Gartner, pl. 3, Figure 13; pl. 9, Figure 6, 8; pl. 25, Figure 15-16

1977 Eiffellithus turriseiffelii (Deflandre) Reinhardt, Verbeek, pl. 5, fig 9

Etymology: (L.) casulus; watchtower

Types: Holotype: Figure 13-A, Paratypes: Figure 13-B, C 

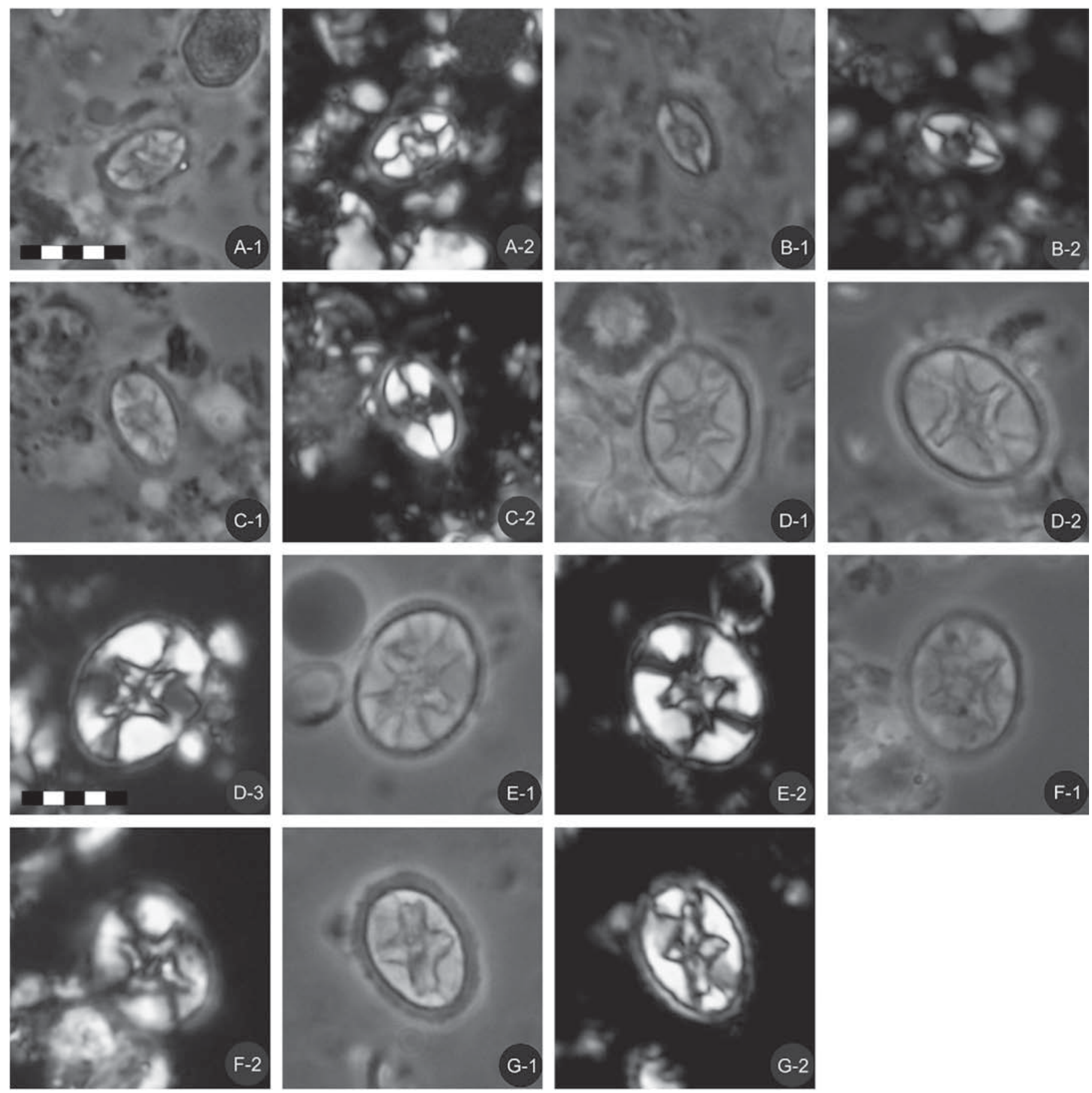

Figure 15. Light photomicrographs of selected specimens at 1250x magnification. Scale bars are $5 \mu \mathrm{m}$ with $1 \mu \mathrm{m}$ divisions. XPL $=$ cross polarized light. PC = phase contrast. A. E. collis (Hoffman 1970), U. Cenomanian, Hartland Mbr, Greenhorn Lst, Loc. 6, 10.25 m; A-1: PC, A-2: XPL. B. E. collis, L. Turonian, Hartland Mbr, Greenhorn Lst, Loc. 6, 13.95 m; B-1: PC, B-2: XPL. C. E. collis U. Cenomanian, Hartland Mbr, Greenhorn Lst, Loc. 6, 9.95 m; C-1: PC, C-2: XPL. D. E. perch-nielseniae n.sp. (holotype), Santonian, DSDP Leg 10-95-17-1-(24-25 cm): D-1, 2: PC, D-3: XPL. E. E. perch-nielseniae (paratype), Santonian, DSDP Leg 10-95-16-1-(124-125 cm); E-1: PC, E-2: XPL. F. E. perch-nielseniae, L. Campanian, Smokey Hill Mbr, Niobrara Chalk, Loc. 20, 19 m; F-1: PC, F-2: XPL. G. E. perch-nielseniae (paratype), L. Campanian, Smokey Hill Mbr, Niobrara Chalk, Loc. 21, 13 m; G-1: PC, G-2: XPL.

Type section: Hartland Mbr, Greenhorn Limestone Fm, Hattin (1975) Loc. 6

Type Level: $0.48 \mathrm{~m}$, upper Cenomanian

Diagnosis: Small to medium, broadly to narrowly elliptical eiffellithid with a stem base consisting of four disjunct cross-bars that form a symmetrical diagonal cross aligned $45^{\circ}-60^{\circ}$ to the longitudinal axis of the coccolith.

Description: Species of eiffellithid with a broadly to normally ellipti- cal rim consisting of 30-60 steeply inclined elements giving a smooth to serrate outline. The inner rims consist of 8-12 radially oriented, roughly triangular back plates, which converge in the center to form an elliptical opening. This opening can occupy $\sim 50 \%$ of the longitudinal axis. Overgrowth of the back plates is common, forming additional crystal boundaries, occasionally obscuring the central opening. This tendency increases up section with younger specimens completely infilled. The rims display first order birefringence, though inner plates 

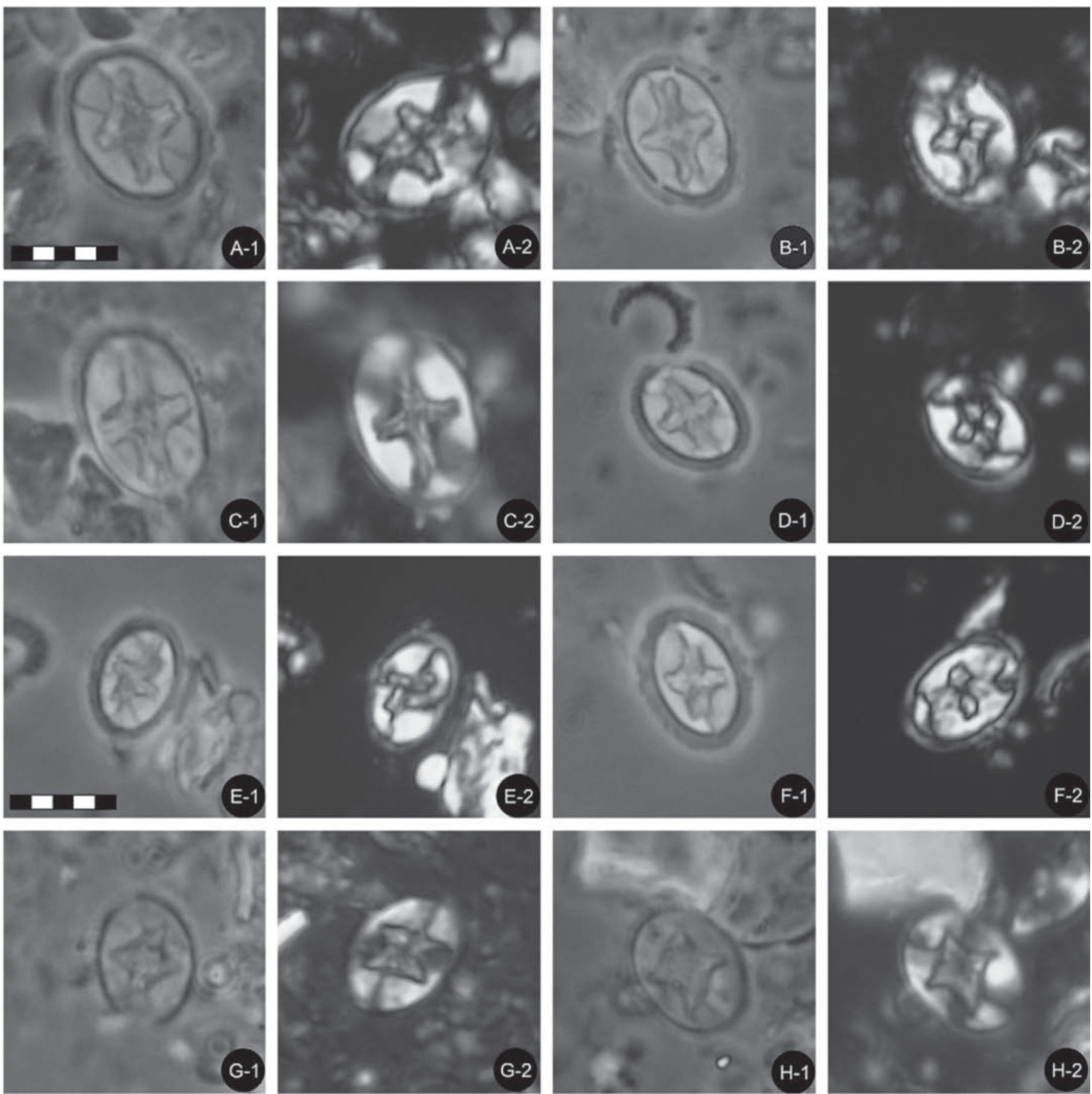

Figure 16. Light photomicrographs of selected specimens at 1250x magnification. Scale bars are $5 \mu \mathrm{m}$ with $1 \mu \mathrm{m}$ divisions. XPL $=\mathrm{cross}$ polarized light. PC = phase contrast. A. E. eximius (Stover, 1966) Perch-Nielsen, 1968, Santonian, DSDP Leg 10-95-16-2-(74-75 cm); A-1: PC, A-2: XPL. B. E. eximius, Santonian, Smokey Hill Mbr, Niobrara Chalk, Loc. 18, 13 m; B-1: PC, B-2: XPL. C. E. eximius, L. Campanian, Smokey Hill Mbr, Niobrara Chalk, Loc. 21, 11.5 m; C-1: PC, C-2: XPL. D. E. nudus n.sp. (holotype), Santonian, DSDP Leg 10-95-16-1-(124-125 cm); D-1: PC, D-2: XPL. E. E. nudus (paratype), Santonian, DSDP Leg 10-95-16-3-(24-25 cm); E-1: PC, E-2: XPL. F. E. nudus (paratype), L. Campanian, Smokey Hill Mbr, Niobrara Chalk, Loc. 20, 15 m; F-1: PC, F-2: XPL. G. E. phantasma n.sp. (paratype), L. Campanian, Gregory Mbr, Pierre Shale, Core 20-3-(5 cm); G-1 PC, G-2: XPL. H. E. phantasma (holotype), L. Campanian, Gregory Mbr, Pierre Shale, Core 21-1-(18 cm); H-1: PC, H-2: XPL.

tend to be much brighter than the outer rim. A symmetrical diagonal cross rises above the central-area. The proximal base is composed of lath-like elements which curve from the diagonal cross-bars to run parallel to the axes before recurving to joint the adjacent cross-bar. Extinction lines run parallel with the axes of the coccolith and divide the cross into four cross-bars which appear distinctly triangular and optically uniform under cross-polarized light. The cross-bars taper to a point $45^{\circ}-60^{\circ}$ to the longitudinal axis. The central opening frequently appears as a small hole. The central cross may have relief, but it is confocal with the coccolith rim. Overgrowth decreases the free length of the cross-bars and gives an hourglass-shaped outline to the base. Measurements:

Length $=4.4-<8.0 \mu \mathrm{m}(\mu=6.0$, s.d. $=0.74, \mathrm{n}=50)$

Width $=3.3-6.1 \mu \mathrm{m}(\mu=4.5$, s.d. $=0.62, \mathrm{n}=50)$

Eccentricity $=1.21-1.50(\mu=1.34$, s.d. $=0.07, \mathrm{n}=50)$

Occurrence: upper Albian - Maastrichtian 

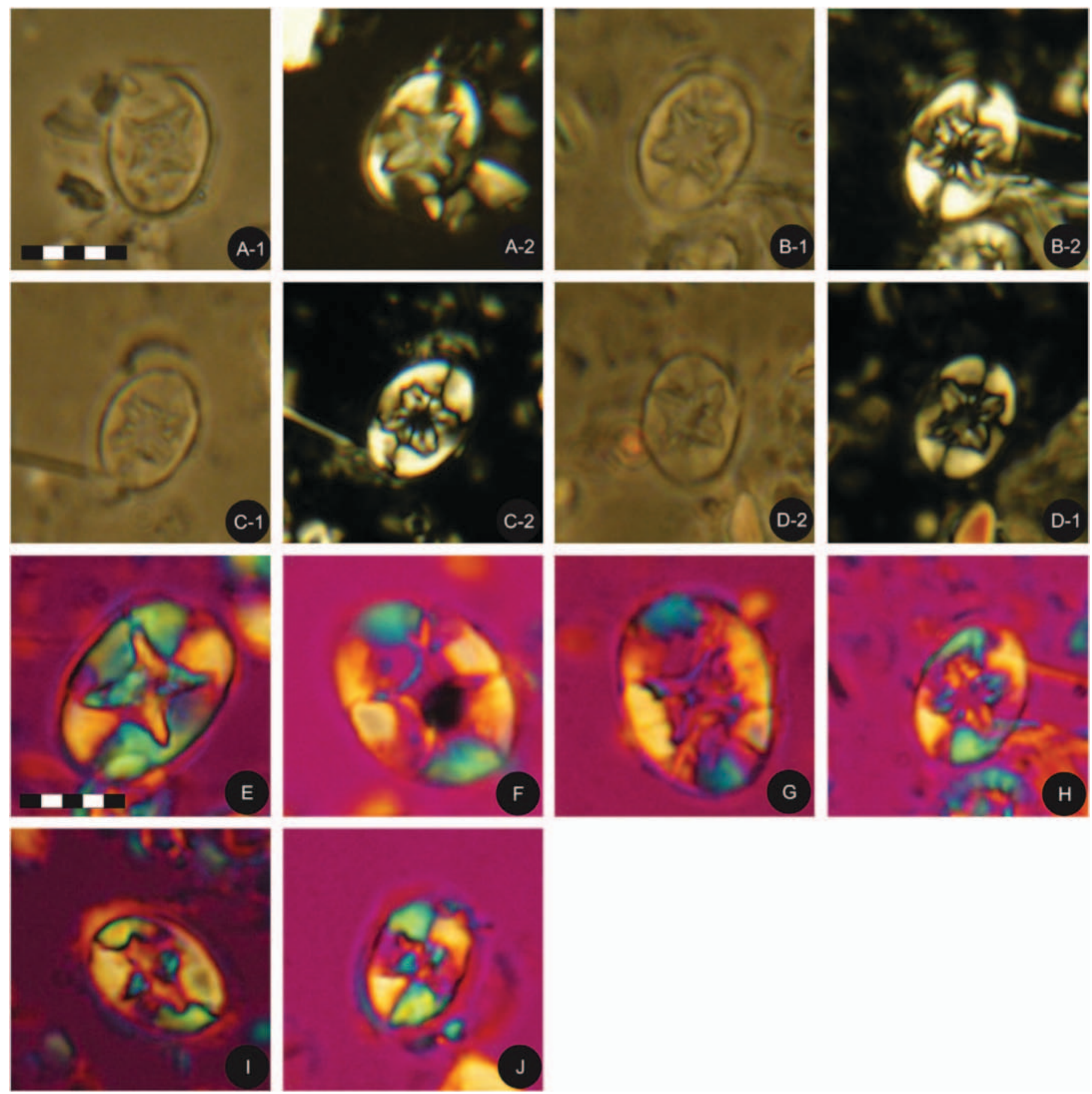

Figure 17. Light photomicrographs of selected specimens at 1250x magnification. Scale bars are $5 \mu \mathrm{m}$ with $1 \mu \mathrm{m}$ divisions. XPL $=$ cross polarized light. $\mathrm{PC}=$ phase contrast. Specimens E-G viewed through a one-quarter $\lambda$ mica plate. A. E. phantasma (paratype), mid-Campanian, Gregory Mbr, Pierre Shale, Core 23-3-(25 cm); A-1: PC, A-2: XPL. B. E. parallelus (Perch-Nielsen, 1973), U. Maastrichtian, ODP Leg 171b-1049a-17-2-(119-126 cm); B-1: PC, B-2: XPL. C. E. parallelus, U. Maastrichtian, ODP Leg 171b-1049a-17-2-(119-126 cm); C-1: PC, C-2: XPL. D. E. parallelus, Maastrichtian, ODP Leg 171b-1050c-13-2-(139 cm); D-1: PC, D-2: XPL. E. E. turriseiffelii, U. Maastrichtian, ODP Leg 171b-1049a-17-2-(119-126 cm). F. E. keio n.sp. (holotype), L. Turonian, Hartland Mbr, Greenhorn Lst, Loc. 6, 13.45 m. G. E. digitatus n.sp., (holotype), L. Turonian, Hartland Mbr, Greenhorn Lst, Loc. 6, 11.35 m. H. E. parallelus, U. Maastrichtian, ODP Leg 171b-1049a-17-2-(119-126 cm); 1: PC, 2: XPL. I. E eximius, M. Santonian, Smokey Hill Mbr, Niobrara Chalk, Loc. 19, 16 m. J. E. casulus, L. Campanian, Smokey Hill Mbr, Niobrara Chalk, Loc. 20, 15 m

Remarks: Though E. casulus is distinguished from the structurally similar E. turriseiffelii by its smaller size. Eiffellithus turriseiffelii averages $9.0 \mu \mathrm{m}$ in length (holotype $9.2 \mu \mathrm{m}$ ), with a minimum length $\geq 8 \mu \mathrm{m}$. The FAD of E. turriseiffelii is approximately $0.6 \mathrm{~m} . \mathrm{y}$. after E. casulus. Eiffellithus casulus tends to retain its stem more frequently, while the opening within the cross is more prominent in E. turriseffelii, whose stem is frequently absent. Eiffellithus casulus can be distinguished from the similar sized E. collis by the blunt, rectangular shape of the central cross in the latter when compared to the pointed, diagonal cross of E. casulus. Eiffellithus collis is also markedly elongate. Eiffellithus gorkiae has a constricted central cross, the back plates completely infill the central-area, and does not appear until the Late Cretaceous. 
Eiffellithus digitatus Shamrock, $n . s p$.

Figure 14, B-D; Figure 17, G

1968 Eiffellithus turriseiffelii, (Deflandre) Reinhardt, Gartner, pl. 13, Figure 2; pl. 23, Figure 10

Etymology: (L.) - having fingers, in reference to the numerous cross-bar terminations.

Types: Holotype: Figure 13-B, 17-G. Paratypes: 13-C, 13-D

Type Section: Hartland Mbr, Greenhorn Limestone Fm, Hattin (1975) Loc. 6

Type Level: $11.35 \mathrm{~m}$, lower Turonian

Diagnosis: Medium to large, broadly to normally elliptical eiffellithid, with a stem base of four irregular cross-bars. The larger cross-bars of this asymmetrical diagonal cross fall $20^{\circ}-44^{\circ}$ from the longitudinal axis of the coccolith.

Description: Species of eiffellithid with a broadly to normally elliptical rim of 40-60 steeply inclined elements giving a smooth to serrate outline. The inner rim consists of 8-15 radially oriented, irregular back plates, which converge in the center to form an elliptical opening. This opening can occupy $>50 \%$ of the long axis. Overgrowth of back plates is common, forming additional crystal boundaries, occasionally obscuring the central opening. Rims display first order birefringence, though inner plates tend to be much brighter than the outer rim. An asymmetrical diagonal cross rises above the central-area. The midline of the larger cross-bar falls $20^{\circ}-44^{\circ}$ of the longitudinal axis of the ellipse. The central cross bears a square-shaped opening which tapers away from the center in well-preserved specimens, though can be overgrown or obscured by the circular stem projecting distally from this base at $60^{\circ}-90^{\circ}$. The central cross may have high relief, making it impossible to focus on the cross-bar terminations and the interior structure simultaneously, though relief appears to decrease up-section. The cross-bars are composed of lath-like crystallites of irregular shape and size, with bifurcate to trifurcate cross-bar terminations that join the inner plates, though can stretch to the outer rim. Trifurcate morphotypes are structurally similar to bifurcates, but with an additional crystallite group between the outer pair. Specimens with $>3$ terminations/cross-bar are occasionally seen. The structure of the intermediate cross can appear chaotic, giving a wide range of morphological diversity to this form.

Measurements:

Length $=7.7-12 \mu \mathrm{m}(\mu=9.2$, s.d. $=0.8, \mathrm{n}=50)$

Width $=5.7-10.2 \mu \mathrm{m}(\mu=7.3$, s.d. $=0.8, \mathrm{n}=50)$

Eccentricity $=1.17-1.41(\mu=1.28$, s.d. $=0.06, \mathrm{n}=50)$

Occurrence: upper Cenomanian - lower Campanian

Remarks: Eiffellithus digitatus can be distinguished from most other species of Eiffellithus by the structure and orientation of the central cross, which falls $20^{\circ}-44^{\circ}$. Asymmetry distinguishes it from its symmetrical ancestor E. keio and from other symmetrical diagonal forms such as $E$. turriseiffelii. The cross-bars fall within $20^{\circ}$ of the longitudinal axis in E. eximius and E. angustus. Eiffellithus perch-nielseniae and E. phantasma have orientations similar to E. digitatus $\left(20^{\circ}-44^{\circ}\right)$ but can be differentiated by the construction of the central cross. Eiffellithus digitatus has a more ornate outline with bifurcate to trifurcate distal morphology on all cross-bars, often with greater than 10 total terminations. Eiffellithus perch-nielseniae shows a much simpler construction, in that only the larger cross-bars show bifurcation, while the transverse cross-bars are tapered and optically uniform. Eiffellithus phantasma is thinner and smaller, with all cross-bars showing a simple, dominantly rounded to blunt, terminal morphology.

Eiffellithus eximius (Stover, 1966) Perch-Nielsen, 1968 Figure 16, A-C; Figure 17, I

1966 Clinorhabdus eximius, Stover, pl. 2, Figure 15-16

1968 Eiffellithus eximius, (Stover), Perch-Nielsen, fig 5a; pl. 3, Figure $8-10$

1968 Eiffellithus turriseiffelii, (Deflandre) Reinhardt, Gartner, pl. 19, fig, 1; pl. 23, Figure11

1999 Eiffellithus eximius, (Deflandre) Reinhardt, Bown, pl. 6.4, Figure 22-23 only

Description: (Note: this description emphasizes the original photographs and sketches of Stover, 1966, to clarify the morphological criteria of the species, and to aid in differentiation from E. angustus and E. nudus). Species of eiffellithid with a broadly to normally elliptical rim, consisting of 40-70 steeply inclined elements, giving a smooth to serrate outline. The central-area consists of 8-15 radially oriented, roughly triangular elements which converge to nearly fill the central-area. Overgrowth of the back plates is common, forming additional crystal boundaries. The coccolith displays first order birefringence, though inner plates tend to be brighter than the outer rim. Above the back plates is a symmetrical to slightly asymmetrical axial cross that spans $60-75 \%$ of the length of the coccolith. The mid-line of the longitudinal cross-bar falls within $20^{\circ}$ of the longitudinal axis of the coccolith. The cross-bars are composed of lath-like elements that gently taper towards the outer rim. Along the transverse axis the cross-bars are shorter, thinner, and taper towards the rim to a pointed, blunt, or weakly clavate terminal morphology. The longitudinal cross-bars can be wider and longer. In larger specimens the longitudinal cross-bars may be widely bifurcate, as the laths of the broader cross-bar spread around the back plates. The cross-bars converge in the center, rising to a low peak. The central cross can be highly birefringent in cross-polarized light, and is dissected into four roughly triangular pieces by extinction lines oriented at $45^{\circ}$ to the axes of the ellipse. When nearly extinct, vague and discontinuous crystal boundaries run down the center of the cross-bars. When present, the stem is roughly circular in phase contrast, but dark in cross-polarized light. When absent the stem base contains a large opening through which the back plates can be seen filling the central-area.

Measurements:

Length $=7.3-10.4 \mu \mathrm{m}(\mu=8.3$, s.d. $=0.66, \mathrm{n}=50)$

Width $=5.2-7.8 \mu \mathrm{m}(\mu=6.2$, s.d. $=0.55, \mathrm{n}=50)$

Eccentricity $=1.23-1.47(\mu=1.33$, s.d. $=0.06, \mathrm{n}=50)$

Occurrence: Turonian - lower Campanian

Remarks: Eiffellithus eximius can be differentiated from most species of Eiffellithus by the orientation of the larger cross-bars, whose midline falls within $20^{\circ}$ of the longitudinal axis of the coccolith. The species concept of E. eximius is similar to that of Stover, 1966 and PerchNielsen, 1968, but can now be statistically distinguished from other axial species by limitations on coccolith size and cross-bar terminal morphology. The central cross of E. nudus is also oriented within $20^{\circ}$ of the longitudinal axis but specimens of this species are $\leq 7.2 \mu \mathrm{m}$ in length while those of E. eximius are $>7.2 \mu \mathrm{m}$ in length. Eiffellithus eximius is similar in size and cross-bar orientation to E. angustus, but all cross-bars are broad, bifurcate, and have prominent crystal boundaries in the latter.

Eiffellithus keio Shamrock, n. sp.

Figure 13, G-H; Figure 14, A; Figure 17, F

1976 Eiffellithus turriseiffeli (Deflandre) Reinhardt, Hill, pl. 2, Figure 37-38

1985 Eiffellithus turriseiffelii A, Perch-Nielsen, Figure 12

Etymology: (Gr.) keio - to cleave or to split, in reference to the distal tip morphology and the lineage that evolves from this form

Types: Holotype: Figure 14-A, 17-F. Paratypes: Figure 13-G, 13-H

Type Section: Hartland Mbr, Greenhorn Limestone Fm, Hattin (1975)

Loc. 6

Type Level: $13.45 \mathrm{~m}$, lower Turonian

Diagnosis: Medium to large, broadly to normally elliptical eiffellithid, with a stem base consisting of four disjunct cross-bars with bifurcate to trifurcate terminations, forming a roughly symmetrical diagonal cross aligned $\geq 45^{\circ}$ to the axes of the coccolith

Description: Species of eiffellithid with a broadly to normally elliptical rim consisting of 40-70 steeply inclined elements giving a smooth to serrate outline. The inner rim consists of 8-15 radially oriented, roughly triangular back plates, which converge in the center to form an elliptical opening. This opening can occupy $>50 \%$ of the long axis. Overgrowth of the back plates is common, forming additional crystal boundaries, occasionally obscuring the central opening. The rims display first order birefringence, though inner plates tend to be much brighter than the outer rim. The cross-bars are symmetrical about the axes, but distal terminations are highly variable both between specimens and within an individual specimen, giving a slightly asymmet- 
rical appearance to the cross itself. Bifurcate to trifurcate terminations occur on all cross-bars, with both lobate and highly forked forms common. Due to the overlapping nature of the crystal laths, the crystal boundaries along each cross-bar are also highly variable. The crossbars rise above the plane of the coccolith, and the resultant base contains a deep, square-shaped opening which tapers away form the center in well-preserved specimens. This structure can be overgrown or obscured by the circular stem projecting distally from this base at $60^{\circ}$ $90^{\circ}$. The central cross has high relief, making it impossible to focus on the cross-bar terminations and central structure simultaneously. Overall the coccolith is thin and whole specimens are rare, though it can be seen frequently through its range as fragments. Fragments containing at least half of the central cross can be positively identified by the highly ornate cross-bar terminations.

Measurements:

Length $=7.3-11.3 \mu \mathrm{m}(\mu=9.0$, s.d. $=1.11, \mathrm{n}=30)$

Width $=5.3-9.5 \mu \mathrm{m}(\mu=7.1$, s.d. $=0.97, \mathrm{n}=30)$

Eccentricity $=1.15-1.42(\mu=1.3$, s.d. $=0.07, \mathrm{n}=30)$

Occurrence: upper Cenomanian - Turonian?

Remarks: Eiffellithus keio can be differentiated from most species by the diagonal central cross whose cross-bars are symmetrical about the axes of the coccolith. Eiffellithus turriseiffelii has blunt, pointed, or weakly forked cross terminations, a simpler cross construction, and is more uniformly birefringent than E. keio. Eiffellithus casulus has blunt to pointed terminations and is considerably smaller in size. Other species with a symmetrical diagonal cross, such as E. parallelus and E. gorkiae, are constructed far differently and have non-overlapping ranges with E. keio.

Eiffellithus nudus Shamrock, $n$. sp. Figure 16, D-F

1968 Eiffellithus turriseiffelii, (Deflandre) Gartner, pl. 17, Figure 3

Etymology: (L.) nudus - naked, bare

Types: Holotype: Figure 16-D. Paratypes: Figure 16-E, 16-F

Type section: DSDP Leg 10 Site 95 Core 6-1

Type Level: $124-125 \mathrm{~cm}$, Santonian

Diagnosis: Small to medium, normally to narrowly elliptical eiffellithid, with a stem base consisting of four triangular to rectangular shaped cross-bars forming an axial cross aligned within $20^{\circ}$ of the longitudinal axes of the coccolith.

Description: Species of eiffellithid with a normally to narrowly elliptical rim, consisting of 30-50 steeply inclined elements, giving a smooth to serrate outline. The central-area consists of 8-15 radially oriented, roughly triangular back plates, which converge in the center. The outer rim displays first order birefringence, though inner plates tend to be much brighter. The disjunct axial cross is composed of lath-like elements which taper towards the rim with pointed to blunt terminations. Extinction lines run $45^{\circ}$ to the axes and divide the cross into four cross-bars. Cross-bars appear optically uniform under cross-polarized light. In the cross center is a small, circular, knob-like stem that sits above the plane of the coccolith.

Measurements:

Length $=5.5-7.0 \mu \mathrm{m}(\mu=6.5$, s.d. $=0.4, \mathrm{n}=50)$

Width $=4.3-5.5 \mu \mathrm{m}(\mu=4.9$, s.d. $=0.3, \mathrm{n}=50)$

Eccentricity $=1.21-1.44(\mu=1.32$, s.d. $=0.06, \mathrm{n}=50)$

Occurrence: Coniacian - lower Campanian

Remarks: Eiffellithus nudus can be differentiated from most species of Eiffellithus by the orientation of the larger cross-bars, whose midline lies within $20^{\circ}$ of the longitudinal axis. Eiffellithus nudus can be distinguished from other axial species of Eiffellithus, such as E. eximius and E. angustus, by its small size and lack of distal bifurcations.

\section{Eiffellithus perch-nielseniae Shamrock, $n$. sp.} Figure 15, D-G

1968 Eiffellithus turriseiffelii (Deflandre) Reinhardt, Gartner, pl. 22, Figure 4; pl. 24 Figure 2; pl. 26, Figure 4

Etymology: In honor of Prof. Katrina Perch-Nielsen
Types: Holotype: Figure 15-D. Paratypes: Figure 15-E, 15-G

Type section: DSDP Leg 10, Hole 95, Core 17-1

Type Level: $24-25 \mathrm{~cm}$, Santonian

Diagnosis: Medium to large, normally elliptical eiffellithid, with a stem base consisting of an asymmetrical diagonal cross whose larger crossbar is $20^{\circ}-44^{\circ}$ from the longitudinal axis.

Description: Medium to large species of eiffellithid with a normally elliptical rim consisting of 40-70 steeply inclined elements, giving a smooth to serrate outline. The inner rim consists of 8-15 radially oriented, polygonal back plates, which converge in the center to form an elliptical opening. This opening is frequently obscured by the central cross. The rims display first order birefringence, though inner plates tend to be much brighter than the outer rim. An asymmetrical diagonal cross sits above the central-area. The stem base is composed of lath-like elements that form four, roughly triangular cross-bars. The midline of the larger cross-bars falls $20^{\circ}-44^{\circ}$ of the longitudinal axis. The length, width, and terminations of these cross-bars are highly variable both between specimens and within an individual specimen, giving the central structure a distinctly asymmetrical outline with respect to both axes of the coccolith. As the central cross approaches the longitudinal axis the larger cross-bars widen and attach between the back plates, causing bifurcation along this direction. The transverse cross-bars are small, simply constructed, and tapered to blunt in outline, similar to its ancestor, E. turriseiffelii. The central cross contains a square-shaped opening in well-preserved specimens, though this can be overgrown or obscured by the circular stem which projects distally from this base at $60^{\circ}-90^{\circ}$.

Measurements:

Length $=6.6-10.3 \mu \mathrm{m}(\mu=8.1$, s.d. $=0.75, \mathrm{n}=50)$

Width $=5.2-7.6 \mu \mathrm{m}(\mu=6.1$, s.d. $=0.37, \mathrm{n}=50)$

Eccentricity $=1.2-1.46(\mu=1.33$, s.d. $=0.06, \mathrm{n}=50)$

Occurrence: upper Cenomanian - Campanian

Remarks: Eiffellithus perch-nielseniae can be distinguished from most species in the genus by the intermediate orientation of the central cross, where the midline of the larger cross-bars lie $20^{\circ}-44^{\circ}$. Eiffellithus turriseiffelii has a symmetrical diagonal cross. In species with an axial cross, the larger cross-bars fall within $20^{\circ}$ of the longitudinal axis. Eiffellithus perch-nielseniae can be distinguished from the intermediately oriented E. digitatus by the relatively simple construction of the central cross in the former. Eiffellithus digitatus is more ornate, with bifurcate to trifurcate cross-bars, often with $>10$ total terminations. Eiffellithus perch-nielseniae can be distinguished from the similarly oriented $E$. phantasma by the generally smaller size and thinner construction of the latter. Eiffellithus perch-nielseniae is very similar in form to the Lower Cretaceous E. vonsalisiae, however there is a $>5 \mathrm{~m}$.y. hiatus between these forms through much of the Cenomanian.

\section{Eiffellithus phantasma Shamrock, $n$. sp.}

Figure 16, G-H; Figure 17, A

\section{Eiffellithus gorkiae, Reinhardt, Hadavi, pl. 1, Figure 17}

Etymology: (Gr.) phantasma; image, ghost, apparition

Types: Holotype: Figure 16-H. Paratypes: Figure 16-G, 17-A

Type section: Gregory Mbr, Pierre Shale, Sisseton, SD Core 21-3

Type Level: $21 \mathrm{~cm}$, lower Campanian

Diagnosis: Medium to large, broadly to normally elliptical eiffellithid, with a disjunct stem base consisting of four, roughly triangular crossbars. The larger cross-bars of this asymmetrical cross are $20^{\circ}-44^{\circ}$ from the longitudinal axis of the coccolith.

Description: Medium to large species of eiffellithid with a rim consisting of 30-60 steeply inclined elements, giving a relatively smooth, broadly to normally elliptical outline. The interior consists of 8-15 thin, radially oriented, roughly triangular back plates, which converge behind the central cross. The thin, outer rim is dim, with the inner plates showing first order birefringence. Although the individual plates can be resolved, the overall appearance is faint when viewed in either phase contrast or cross-polarized light. An asymmetrical diagonal cross sits slightly above the central-area. The low peak can be seen well in phase contrast illumination. The interference of the lamella can give the central cross a petaloid appearance around the stem, as short 
extinction lines partially bisect, but do not extend the full length of, the cross-bars. The cross-bars closest to the longitudinal axis, though generally larger, can be similar in size to the pair nearer the transverse axis. This species can be readily identified by the outline of the cross in phase contrast, which resembles an asymmetrical hourglass (Figure 15G-1).

Measurements:

Length $=5.6-8.4 \mu \mathrm{m}(\mu=6.8$, s.d. $=0.5, \mathrm{n}=50)$

Width $=4.1-6.1 \mu \mathrm{m}(\mu=5.1$, s.d. $=0.5, \mathrm{n}=50)$

Eccentricity $=1.22-1.48(\mu=1.33$ s.d. $=0.06, \mathrm{n}=50)$

Occurrence: lower Campanian - Maastrichtian

Remarks: Eiffellithus phantasma can be differentiated from most species of Eiffellithus by the intermediate orientation of the central cross $\left(20^{\circ}-\right.$ $\left.44^{\circ}\right)$. Eiffellithus phantasma can be differentiated from other intermediately oriented forms by the thinness of the plates and the terminal morphologies of the cross-bars. Eiffellithus perch-nielseniae is a robust, highly birefringent form. The longitudinal cross-bars are notably longer than the transverse cross-bars. Eiffellithus digitatus, which can also be thin, is typically larger and has highly ornate cross-bar morphology, with bifurcate to trifurcate terminations. The Campanian first appearance of E. phantasma is widely separate from the first appearance of other intermediates, which appear in the upper Cenomanian to Turonian.

Eiffellithus turriseiffelii (Deflandre and Fert, 1954) Reinhardt 1965 amended herein

Figure 13, D-F; Figure 17, F

1954 Zygolithus turriseiffeli, Deflandre, pl. 13, Figure 15-16 (holotype) 1965 Eiffellithus turriseiffeli (Deflandre), Reinhardt, p. 32

1966 Clinorhabdus turriseiffeli (Deflandre), Stover, pl. 3, Figure 7-9

1968 Eiffellithus turriseiffeli (Deflandre) Reinhardt, Gartner, pl. 2, Figure 22; pl. 5, Figure 19; pl. 6, Figure 7; pl. 18, Figure 11; pl. 23, Figure 7 1976 Eiffellithus turriseiffelii (Deflandre) Reinhardt, Hill, pl. 6, Figure 39-42; pl. 14, Figure 8-9

Emended diagnosis: Large, broadly to normally elliptical eiffellithid, with a disjunct stem base consisting of four cross-bars that form a symmetrical diagonal cross aligned $45^{\circ}-60^{\circ}$ to the longitudinal axis of the coccolith
Description: Species of eiffellithid with a broadly to normally elliptical rim consisting of 50-70 steeply inclined elements that give a smooth to serrate outline. The inner rim consists of 8-15 radially oriented, roughly triangular back plates, which converge to form a central elliptical opening. This opening can occupy $>50 \%$ of the longitudinal axis. Overgrowth of the back plates is common, forming additional crystal boundaries, occasionally obscuring this opening. The central-area is increasingly filled in younger forms. The rims display first order birefringence, though the broad inner cycle is much brighter than the outer rim. A symmetrical diagonal cross rises above the central-area. The proximal base is composed of lath-like elements which curve from the diagonal to run parallel to the axes before recurving to join the adjacent cross-bar. Small extinction lines run parallel with the axes of the coccolith and divide the central cross into four units that appear roughly triangular and optically uniform under cross-polarized light. The cross-bars are of equal length and terminal morphology, typically tapered to blunt. A square-shaped opening sits within the central cross, and tapers away from the center in well-preserved specimens, though this can be overgrown or obscured by the circular stem projecting distally from this base at $60-90^{\circ}$. The central cross may have high relief, making it impossible to focus on the cross-bar terminations and central structure simultaneously, though this tendency decreases up section. Small forked tips may occasionally be present, however, this is a vestigial characteristic. Overgrowth reduces the free length of the cross-bars and may give an hour-glass outline to the central cross. Measurements:

Length $=\geq 8.0-11.5 \mu \mathrm{m}(\mu=8.8$, s.d. $=0.5, \mathrm{n}=50)$

Width $=5.6-8.3 \mu \mathrm{m}(\mu=6.6$, s.d. $=0.6, \mathrm{n}=50)$

Eccentricity $=1.22-1.47(\mu=1.36$, s.d. $=0.07, \mathrm{n}=50)$

Occurrence: uppermost Albian - Maastrichtian

Remarks: Eiffellithus casulus can be distinguished from E. turriseiffelii by its smaller size, averaging $6.0 \mu \mathrm{m}$ in length, with a maximum length of $<8 \mu \mathrm{m}$. The large morphotype $\left(\mu_{\text {length }}=8.7 \mu \mathrm{m}\right.$, holotype $\left.=9.2 \mu \mathrm{m}\right)$ has retained the name E. turriseiffelii, as it is the type-species for the genus and carries historical precedent. Eiffellithus turriseiffelii can be distinguished from E. keio by the pointed to weakly forked cross-bar terminations in the former, in contrast to the highly ornate, bifurcate to trifurcate terminations which distinguish the latter. The central cross of E. parallelus is composed of parallel lamellae in contrast to the curving elements in E. turriseiffelii. 